\title{
Review \\ Nicotinamide Adenine Dinucleotide Phosphate Oxidases in Glucose Homeostasis and Diabetes-Related Endothelial Cell Dysfunction
}

\author{
Oliver Ian Brown (D), Katherine Isabella Bridge and Mark Thomas Kearney * \\ Leeds Institute of Cardiovascular and Metabolic Medicine, University of Leeds, Leeds LS2 9JT, UK; \\ medoib@leeds.ac.uk (O.I.B.); k.bridge@leeds.ac.uk (K.I.B.) \\ * Correspondence: m.t.kearney@leeds.ac.uk
}

check for updates

Citation: Brown, O.I.; Bridge, K.I.; Kearney, M.T. Nicotinamide Adenine Dinucleotide Phosphate Oxidases in Glucose Homeostasis and Diabetes-Related Endothelial Cell Dysfunction. Cells 2021, 10, 2315. https://doi.org/10.3390/cells10092315

Academic Editor: Eun Seong Hwang

Received: 29 July 2021

Accepted: 1 September 2021

Published: 4 September 2021

Publisher's Note: MDPI stays neutral with regard to jurisdictional claims in published maps and institutional affiliations.

Copyright: (c) 2021 by the authors. Licensee MDPI, Basel, Switzerland. This article is an open access article distributed under the terms and conditions of the Creative Commons Attribution (CC BY) license (https:// creativecommons.org/licenses/by/ $4.0 /)$.

\begin{abstract}
Oxidative stress within the vascular endothelium, due to excess generation of reactive oxygen species (ROS), is thought to be fundamental to the initiation and progression of the cardiovascular complications of type 2 diabetes mellitus. The term ROS encompasses a variety of chemical species including superoxide anion $\left(\mathrm{O}_{2}{ }^{\bullet-}\right)$, hydroxyl radical $\left(\mathrm{OH}^{-}\right)$and hydrogen peroxide $\left(\mathrm{H}_{2} \mathrm{O}_{2}\right)$. While constitutive generation of low concentrations of ROS are indispensable for normal cellular function, excess $\mathrm{O}_{2}{ }^{\bullet-}$ can result in irreversible tissue damage. Excess ROS generation is catalysed by xanthine oxidase, uncoupled nitric oxide synthases, the mitochondrial electron transport chain and the nicotinamide adenine dinucleotide phosphate (NADPH) oxidases. Amongst enzymatic sources of $\mathrm{O}_{2}{ }^{\bullet-}$ the Nox2 isoform of NADPH oxidase is thought to be critical to the oxidative stress found in type 2 diabetes mellitus. In contrast, the transcriptionally regulated Nox4 isoform, which generates $\mathrm{H}_{2} \mathrm{O}_{2}$, may fulfil a protective role and contribute to normal glucose homeostasis. This review describes the key roles of Nox2 and Nox4, as well as Nox1 and Nox5, in glucose homeostasis, endothelial function and oxidative stress, with a key focus on how they are regulated in health, and dysregulated in type 2 diabetes mellitus.
\end{abstract}

Keywords: NADPH oxidases; NADH; NADPH; Nox; type 2 diabetes mellitus; endothelial function; oxidative stress; reactive oxygen species; atherosclerosis

\section{Introduction}

Reactive oxygen species (ROS) are a by-product of oxygen metabolism [1]. The term ROS encompasses a variety of diverse chemical species including the superoxide anion $\left(\mathrm{O}_{2}{ }^{\bullet-}\right)$, hydroxyl radical $\left({ }^{\bullet} \mathrm{OH}\right)$ and hydrogen peroxide $\left(\mathrm{H}_{2} \mathrm{O}_{2}\right) \cdot \mathrm{O}_{2}{ }^{\bullet-}$ and $\bullet \mathrm{OH}^{\circ}$ are extremely unstable, whereas $\mathrm{H}_{2} \mathrm{O}_{2}$ is uncharged, stable and can cross membranes freely, making it a more versatile signalling molecule [2,3]. Knowledge generated over the last three decades has revealed a diverse repertoire of actions for ROS including regulation of cell growth, migration, proliferation and metabolism [4]. ROS can be generated as a result of a number of different cellular processes, including: xanthine oxidase reactions, uncoupled nitric oxide synthases, the mitochondrial electron transport chain and by the nicotinamide adenine dinucleotide phosphate (NADPH) oxidases (Nox) [5].

The discovery of the Nox isoforms (Nox1-Nox5), whose only known function is to catalyse the synthesis of ROS [6,7], and the seminal finding that Nox4, which is transcriptionally regulated, generates $\mathrm{H}_{2} \mathrm{O}_{2}$, as opposed to superoxide, highlights the fact that ROS are not uniformly toxic, and may serve important physiological roles $[8,9]$.

Type 2 diabetes mellitus is characterised by insulin resistance, inflammation, dyslipidaemia, dysglycaemia and intracellular nutrient overload. In endothelial cells (EC), this results in excessive generation of ROS, a situation often described as 'oxidative stress' or 'endothelial dysfunction' [1,10]. Large scale genetic studies support an emerging paradigm 
that puts oxidative stress at the centre of the pathophysiology of the insulin resistance associated with type 2 diabetes mellitus, and its associated cardiovascular complications. [11,12]. Consistent with this, insulin resistance, induced by a range of mechanisms in murine models of type 2 diabetes mellitus, leads to cytotoxic levels of $\mathrm{O}_{2}{ }^{\bullet-}$, principally produced by the Nox2 isoform of NADPH oxidase (Nox2) [13-16]. Furthermore, it has been shown that expression of NADPH oxidase is increased within the endothelium of overweight and obese human subjects, [17] as well as patients with type 2 diabetes mellitus, resulting in an increase in EC generation of $\mathrm{O}_{2}{ }^{\bullet-}$ [18]. The substantial dataset demonstrating the effect of oxidative stress in humans and preclinical models underpins its potential as a therapeutic target to mitigate the risks of accelerated cardiovascular disease in type 2 diabetes mellitus. However, a non-specific approach to reduce oxidative stress with various antioxidants has failed to improve clinical outcomes, with meta-analyses of clinical trials showing that antioxidants may even increase mortality [19].

The aim of this review is to describe the role of Nox in glucose homeostasis, endothelial function and oxidative stress, with a key focus on how they are regulated in health and dysregulated in type 2 diabetes mellitus.

\section{Formation of ROS}

Synthesis of ROS is catalysed by xanthine oxidase, uncoupled nitric oxide synthase (NOS), the mitochondrial electron transport chain and the NADPH oxidases [7,20-22].

Xanthine oxidase, a form of xanthine oxidoreductase, catalyses the oxidation of hypoxanthine to xanthine, and of xanthine to uric acid-the last two steps of purine catabolism [23]. Transfer of electrons during these two steps, using molybdopterin, two iron-sulphur centres and flavin adenine dinucleotide (FAD) as co-factors, leads to the formation of $\mathrm{H}_{2} \mathrm{O}_{2}$ and $\mathrm{O}_{2}{ }^{\bullet-}$ from $\mathrm{O}_{2}$ [23].

Nitric oxide synthases (NOS) catalyse the transformation of L-arginine, $\mathrm{O}_{2}$ and NADPH derived electrons to nitric oxide (NO) [24]. Tetrahydrobiopterin $\left(\mathrm{BH}_{4}\right)$ is a crucial co-factor in this reaction, acting as a rapid auxiliary electron donor, stabilising the process of electron transfer. When $\mathrm{BH}_{4}$ availability is reduced, the electron transfer process is too slow and NOS catalyses the reduction of $\mathrm{O}_{2}$ to $\mathrm{O}_{2}{ }^{-}{ }^{-}$, rather than the formation of $\mathrm{NO}-\mathrm{a}$ phenomenon known as NOS uncoupling [24]. Furthermore, $\mathrm{BH}_{4}$ is rapidly degraded by $\mathrm{O}_{2}{ }^{\bullet-}$, leading to a vicious cycle, where oxidative stress worsens $\mathrm{BH}_{4}$ availability, thus further potentiating the problem [25].

$\mathrm{NO}$ is a critical anti-oxidant and anti-inflammatory signalling radical that has favourable effects on inflammation, thrombosis, EC death, vascular tone, and angiogenesis. NO is synthesized in EC principally by endothelial NOS (eNOS) [26]. In the short term, the bioavailability and actions of $\mathrm{NO}$ are modulated by ROS, specifically $\mathrm{O}_{2}{ }^{\bullet-}$ [27]. In the longer term, eNOS activity can be regulated at the transcriptional, post-transcriptional and post-translational levels [26,28].

Aside from NO, EC function is dependent on the action of prostanoids-products of arachidonate metabolism via the action of cyclooxygenases (COX) [29]. Several types of prostanoids exist including: prostaglandin $\mathrm{D} 2\left(\mathrm{PGD}_{2}\right)$, prostaglandin $\mathrm{I} 2\left(\mathrm{PG}_{\mathrm{I} 2}\right)$, prostaglandins $\mathrm{F} 2 \alpha\left(\mathrm{PGF}_{2 \alpha}\right)$, prostaglandin E2 $\left(\mathrm{PGE}_{2}\right)$, and thromboxane A2 $\left(\mathrm{TXA}_{2}\right)$. Prostaglandin H2 $\left(\mathrm{PGH}_{2}\right)$ is an important intermediary step in their synthesis and is converted into specific prostanoids by various prostanoid synthases [29]. $\mathrm{PGE}_{2}$ and $\mathrm{PG}_{\mathrm{I}}$ act as vasodilators whilst $\mathrm{TXA}_{2}$ and $\mathrm{PGF}_{2 \alpha}$ induce vasoconstriction [29]. $\mathrm{PGD}_{2}$ has variable effects on vascular tone depending on site and concentration [30]. Importantly, the activity of COX, prostanoid synthases and therefore prostanoid production is regulated by ROS. COX stimulates production of the vasoconstricting $\mathrm{PGE}_{2}$ and $\mathrm{TXA}_{2}$, which in turn stimulates production of ROS by Nox, $\mathrm{O}_{2}{ }^{\bullet-}$ produced by Nox then activates COX leading to a vicious cycle of self-perpetuating endothelial dysfunction [31].

ROS are generated in the mitochondria due to mitochondrial inefficiency during the electron transport chain, with mitochondrial ROS being the major intracellular source of ROS under physiological conditions. As electrons pass sequentially along mitochondrial 
transmembrane protein complexes (I, II and III), approximately $0.2-2 \%$ of electrons leak out of the transport chain. These electrons react with $\mathrm{O}_{2}$ within the mitochondria to form $\mathrm{O}_{2}{ }^{\bullet-}$ and $\mathrm{H}_{2} \mathrm{O}_{2}$ [22].

Nox are a family of membrane-spanning protein complexes which generate extracellular ROS by the transfer of electrons from NADPH to oxygen, resulting in the formation of $\mathrm{O}_{2}{ }^{\bullet-}$ and $\mathrm{H}_{2} \mathrm{O}_{2}$ [32]. At least seven isoforms of the catalytic component of Nox exist (Nox1, Nox2, Nox3, Nox4, Nox5, DUOX1 and DUOX2) and their unifying function is that they only serve to produce ROS [5]. Distribution of specific Nox isoforms within the body is highly variable in terms of tissue and cell type. However, only Nox1, Nox2, Nox4 and Nox 5 are expressed within EC and will therefore be the focus of this review.

\section{ROS and Endothelial Cell Function}

Intracellular production of ROS in the endothelium occurs under physiological as well as pathophysiological conditions. $\mathrm{H}_{2} \mathrm{O}_{2}$ is small, stable, and non-polar and is thus able to freely diffuse across membranes, playing a vital role in the activation of a number of cell signalling pathways. $\mathrm{H}_{2} \mathrm{O}_{2}$ stimulates transcription of a number of different signalling proteins including vascular endothelial growth factor (VEGF) and protein C-ets-1 which promote EC proliferation, tube formation and angiogenesis [30]. The relationship of $\mathrm{H}_{2} \mathrm{O}_{2}$ with oxidative stress is thought to be bell-shaped [4]. Low concentrations of $\mathrm{H}_{2} \mathrm{O}_{2}$ increase production of $\mathrm{NO}$ by upregulating expression of eNOS, and by direct activation of cyclic guanosine monophosphate (cGMP) through activation of protein kinase-G I $\alpha$, inducing thiol oxidation and subsequent eNOS dimerisation $[33,34]$. In addition, $\mathrm{H}_{2} \mathrm{O}_{2}$ increases phosphorylation and activation of the insulin receptor (IR) by oxidising cystine residues, and can activate Akt and eNOS, thus amplifying the insulin signalling cascade [35,36]. At high concentrations, $\mathrm{H}_{2} \mathrm{O}_{2}$ increases cell surface expression of intercellular adhesion molecule-1 (ICAM-1), platelet activating factor (PAF), P-selectin and monocyte chemoattractant protein-1 (MCP-1). These proinflammatory proteins mediate neutrophil adhesion to the endothelium and lead to accelerated atherosclerosis [37].

\section{The Role of Nox in ROS Production}

Human ECs express four Nox isoforms; Nox1, Nox2, Nox4 and Nox5. Nox1, Nox2 and Nox5 promote endothelial dysfunction, inflammation and apoptosis in the vessel wall through the generation of superoxide. All Nox isoforms are unified in their structure by the presence of a catalytic six transmembrane domain protein complex (see Figure 1A) [6]. The N-terminal transmembrane domain of this protein complex binds two heme groups, and the C-terminal domain binds to flavin adenine dinucleotide (FAD) which in turn binds with NADPH to form the Nox complex [6]. Furthermore, all Nox isoforms (with the exception of Nox5) are reliant on p22phox, a membrane anchored subunit for their activity (see Figure 1A) [7]. However, there are significant differences in the regulatory cytosolic subunits required for each Nox isoform to be active.

Nox1 and Nox2 are close structural homologs. Nox1 is localised in the peri-nuclear cytoplasmic skeleton, endoplasmic reticulum, caveolae and nuclear membrane whilst Nox2 is located in the plasma membrane, endoplasmic reticulum and the perinuclear cytoplasmic skeleton [6,7]. Nox1 and Nox2 require similarly acting regulatory cytosolic subunits to be active: Nox1 requires the activation of NOXA1, NOXO1, p40phox and Rac whilst Nox2 requires the activation ofp47phox (a functional homolog of NOXO1), p40phox, p67phox (a functional homolog of NOXA1), and Rac (see Figure 1A).

Nox4 has a similar membrane bound structure to Nox1/Nox2, and is located within the endoplasmic reticulum, plasma and nuclear membranes. However, unlike Nox1 and Nox2, Nox4 does not require cytosolic subunits for its activity and appears to be constitutively active [7,32]. Nox5 does not have any regulatory cytosolic subunits and is unique in that it contains a calmodulin-like domain and is activated by changes in intracellular $\mathrm{Ca}^{2+}[6,38]$. 


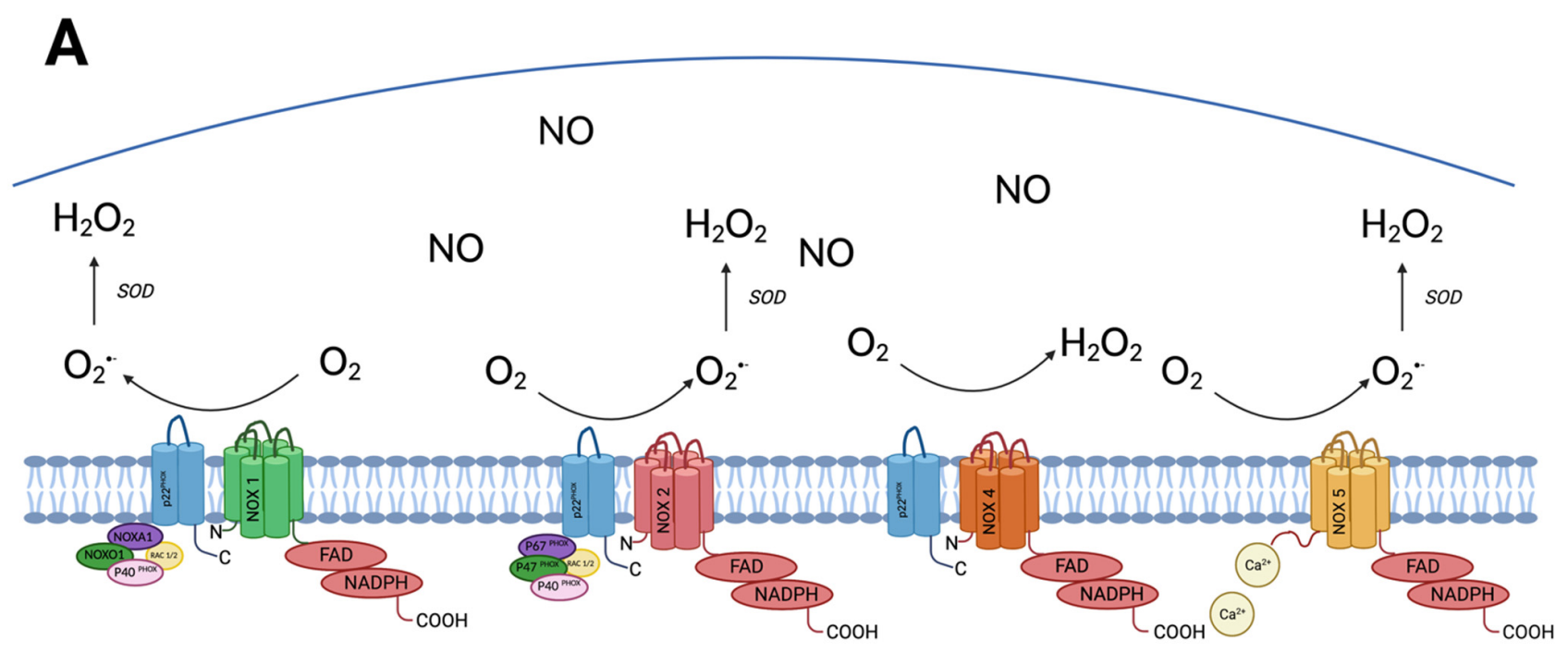

B
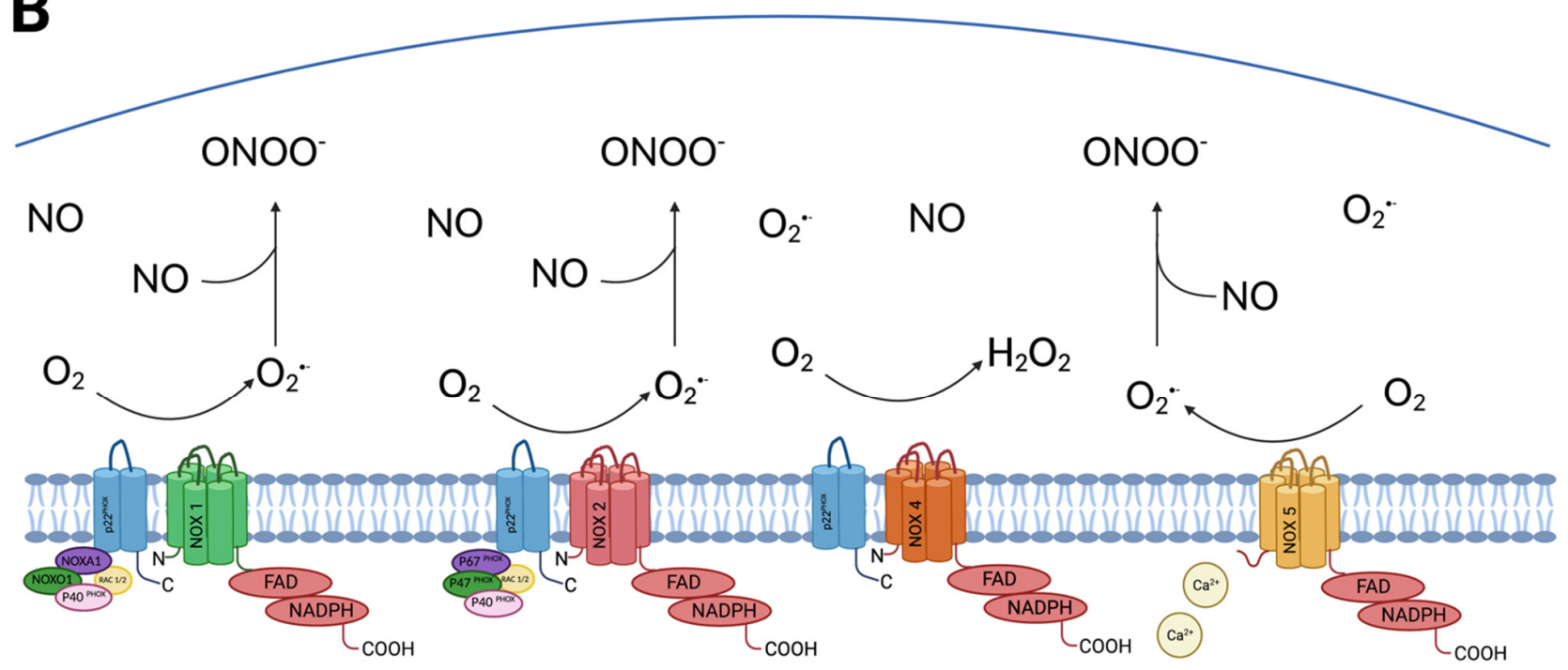

Figure 1. Panel (A) Structure and function of Nox1-5 isoforms of NADPH oxidase and their function in health: Nox1-5 all contain a catalytic six transmembrane domain protein complex, the N-terminal transmembrane domain of this protein complex binds two heme groups, and the C-terminal domain binds to FAD which in turn binds with NADPH to form the NADPH oxidase complex. All Nox isoforms (except Nox5) are reliant on p22phox, a membrane anchored subunit for their activity. Differences exist amongst the regulatory cytosolic subunits required for each Nox isoform. Nox1 requires activation of regulatory subunits NOXA1, NOXO1, p40phox and Rac whilst Nox2 (also called gp91phox) requires the activation of regulatory subunits $\mathrm{p} 47 \mathrm{phox}$, $40 \mathrm{phox}$, and Rac to be active. Nox 5 does not require any regulatory cytosolic subunits and is unique in that it contains a calmodulin-like domain and is activated by changes in intracellular $\mathrm{Ca}^{2+}$. Nox1, 2 and 5 isoforms of NADPH oxidase complex reduces oxygen to produce the $\mathrm{O}_{2}{ }^{\bullet-}$ which is dismutated to $\mathrm{H}_{2} \mathrm{O}_{2}$ by SOD. Dismutation of $\mathrm{O}_{2}{ }^{\bullet-}$ increases the bioavailability of NO. Nox4 does not require cytosolic subunits for its activity and appears to be constitutively active. Unlike all other Nox isoforms, the $\mathrm{O}_{2}{ }^{\bullet-}$ produced by Nox4 is rapidly converted to $\mathrm{H}_{2} \mathrm{O}_{2}$ so production of $\mathrm{O}_{2}{ }^{\bullet-}$ by Nox4 is essentially undetectable. Panel (B) The role of Nox1-5 in diabetes related endothelial dysfunction. The expression and activity of Nox1, 2 and 5 is increased in disease states like diabetes. This leads to increased production of $\mathrm{O}_{2}{ }^{\bullet-}$ which combines with $\mathrm{NO}$ to form $\mathrm{ONOO}^{-}$, a very potent oxidiser and reduces the bioavailability of NO resulting in endothelial dysfunction. Abbreviations: flavin adenine dinucleotide (FAD), hydrogen peroxide $\left(\mathrm{H}_{2} \mathrm{O}_{2}\right)$ nicotinamide adenine dinucleotide phosphate (NADPH), nitric oxide (NO) peroxynitrite $\left(\mathrm{ONOO}^{-}\right)$, superoxide dismutase (SOD). Created with BioRender.com (accessed on 31 August 2021). 
Nox1, Nox2 and Nox5 generate superoxide anions by reducing $\mathrm{O}_{2}$ to $\mathrm{O}_{2}{ }^{\bullet-}$, by transferring electrons from NADPH in the cytosol to oxygen on the extracellular surface (see Figure 1B).

The mechanism of $\mathrm{O}_{2}{ }^{\bullet-}$ related tissue damage is largely twofold. Firstly, $\mathrm{O}_{2}{ }^{\bullet-}$ is highly reactive with transition metal complexes, disrupting mitochondrial function [39]. Secondly, $\mathrm{O}_{2}{ }^{\bullet-}$ rapidly inactivates NO. Not only does this reduce the bioavailability of $\mathrm{NO}$, but the reaction between $\mathrm{O}_{2}{ }^{\bullet-}$ and $\mathrm{NO}$ produces peroxynitrite $\left(\mathrm{ONOO}^{-}\right)$, a potent oxidant [27]. $\mathrm{ONOO}^{-}$can cause oxidative damage directly through reactions with key protein moieties such as thiols, iron/sulphur centres and through tyrosine nitration. Furthermore, $\mathrm{ONOO}^{-}$oxidises $\mathrm{BH}_{4}$, an essential cofactor of eNOS, which leads to oxygen reduction uncoupling from $\mathrm{NO}$ synthesis, and increased formation of $\mathrm{O}_{2}{ }^{--}$[40]. $\mathrm{ONOO}^{-}$ can also cause oxidative damage indirectly, by decomposition into other reactive radicals such as ${ }^{\bullet} \mathrm{OH}[27,41] .^{\bullet} \mathrm{OH}$ can react with DNA, proteins and lipids within the cell leading to significant oxidative damage [37]. $\mathrm{O}_{2}{ }^{\bullet-}$ is rapidly scavenged by superoxide dismutase (SOD) into $\mathrm{H}_{2} \mathrm{O}_{2}$, negating its oxidising effects. We have previously demonstrated, through EC specific inactivation of Shc homology 2-containing inositol 5' phosphatase-2 (SHIP2), a lipid phosphatase that inhibits insulin signalling downstream of PI3K, that Nox2-derived endothelial ROS production is dependent on the P13K/Akt pathway. [42]

Unlike other Nox isoforms, the $\mathrm{O}_{2}{ }^{\bullet-}$ produced by Nox4 is rapidly converted to $\mathrm{H}_{2} \mathrm{O}_{2}$, rendering the production of $\mathrm{O}_{2}{ }^{\bullet-}$ by Nox4 essentially undetectable. [32]

\section{Regulation of Nox}

The regulation of Nox is summarised in Figure 2.

\subsection{Transcriptional Regulation of Nox}

In humans, the genes encoding Nox 1 and Nox 2 can be found on the $\mathrm{X}$ chromosome, whilst Nox4 and Nox 5 can be found on chromosome 11 and 15 respectively [7,43]. A wide variety of protein signalling cascades, hormones and cytokines including mitogen activated protein kinase (MAPK), interferon gamma (IFN $\gamma$ ), tumour necrosis factor alpha (TNF- $\alpha$ ), transforming growth factor beta (TGF- $\beta$ ), and angiotensin II act to increase Nox through transcription factors [44-47]. Nox expression is negatively regulated by JunD [48]. Initial work identified peroxisome proliferator-activated receptor gamma (PPAR- $\gamma$ ) as a negative regulator of Nox, [49] however recent work has suggested Nox-dependent generation of $\mathrm{O}_{2}{ }^{\bullet-}$ is dependent on other types of PPAR (PPAR $\alpha$ and PPAR $\beta / \delta$ ) [50]. Nox1 expression is upregulated by a number of transcription/growth factors including: platelet derived growth factor (PDGF), activating transcription factor-1 (ATF-1), signal transducer and activator of transcription protein (STAT), AP-1 and NF- $\mathrm{KB}$ [51,52]. In addition, proinflammatory cytokines (interleukin-1 and IFN $\gamma$ ); angiotensin II and PGF2 $\alpha$ increased Nox1 activity $[53,54]$. Nox 2 promoter activity is increased by, but not limited to: transcription factor PU.1, E74-like factor 1 (Elf-1), interferon regulatory factors 1 (IRF-1), interferon consensus sequence binding protein (ICSB), activator protein 1 (AP-1), STAT, CCAAT/enhancerbinding proteins $(\mathrm{C} / \mathrm{EBP})$ and nuclear factor kappa-light-chain-enhancer of activated $\mathrm{B}$ cells (NF-kB) $[45,50,55,56]$.

Nox4 is constitutively active and is regulated by large number of transcription factors that promote its expression including: nuclear factor erythroid 2-related factor 2(Nrf2), Smad2, Smad3, E2F, hypoxia-inducible factor 1-alpha (HIF1 $\alpha$ ), C/EBP, AP-1 and NF$\kappa B[43,45]$. Angiotensin II has been shown to more potently activate Nox2 than Nox4 [57,58]. In specific relation to Nox4, PDGF also reduces Nox4 messenger RNA (mRNA) [43]. Protein phosphatase 2 (PP2A) downregulates Nox2 expression, with inhibition of PP2A in rats being shown to exacerbate non-alcoholic steatohepatitis (a disease associated with metabolic syndrome and type 2 diabetes mellitus) [59]. In addition, endoplasmic reticulum stress upregulates Nox1-5 expression [60,61]. 


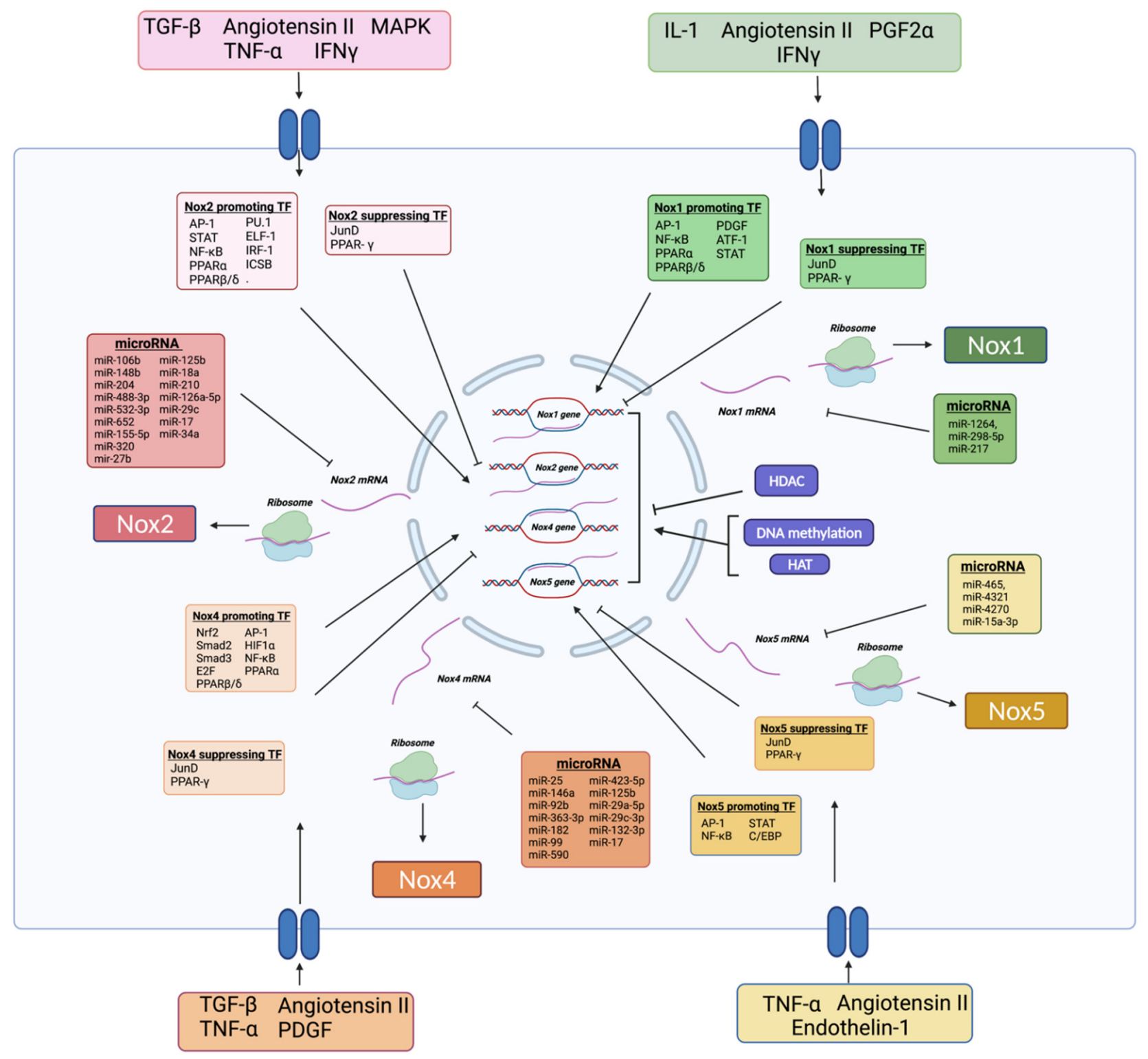

Figure 2. Transcriptional and epigenetic regulation of Nox. A variety of protein kinases, hormones and cytokines act to modulate transcription of Nox through Nox promoting and suppressing transcription factors. Epigenetic mechanisms play a major role regulating Nox. Within the nucleus, HDACs de-acetylate histone proteins, reducing chromatin relaxation and suppressing Nox transcription. In addition, histone acetylation (HAT) and DNA methylation increase Nox activity. Following gene transcription, Nox mRNA is degraded by a wide variety of miRs before being translated into Nox protein within ribosomes. Abbreviations: activator protein 1 (AP-1), activating transcription factor-1 (ATF-1), CCAAT/enhancerbinding proteins (C/EBP), E74-like factor 1 (ELF-1), histone deacetylation (HDAC), hypoxia-inducible factor 1 alpha (HIF1 $\alpha$ ), interferon consensus sequence binding protein (ICSB), interferon gamma (IFN- $\gamma$ ) Interferon regulatory factor-1 (IRF-1) messenger RNA (mRNA), microRNA (miR), mitogen-activated protein kinase (MAPK), Nox1 isoform of NADPH oxidase (Nox1), Nox2 isoform of NADPH oxidase (Nox2), Nox4 isoform of NADPH oxidase (Nox4), Nox5 isoform of NADPH oxidase (Nox5), nuclear factor kappa-light-chain-enhancer of activated B cells (NF- $\mathrm{kB}$ ), peroxisome proliferator-activated receptor (PPAR), platelet derived growth factor (PDGF), prostaglandin F2 $\alpha$ (PGF2 $\alpha$ ), signal transducer and activator of transcription protein (STAT), transforming growth factor- $\beta$ (TGF- $\beta$ ), transcription factor (TF), tumour necrosis factor $\alpha$ (TNF- $\alpha$ ). Created with BioRender.com (accessed on 31 August 2021).

The promotor region of the Nox5 gene has binding sites for multiple transcription factors including: AP-1, NF-кB, STAT and C/EBP [56,62]. In addition, expression of Nox5 mRNA is significantly increased by angiotensin II, endothelin-1 and TNF- $\alpha$ [62]. 


\subsection{Epigenetic Regulation of Nox}

Epigenetic mechanisms, including the activity of histone methylators/deacetylases/ acetylators, DNA methylation and microRNAs (miRs), have been postulated as playing a significant role in the regulation of Nox expression [63].

Histone deacetylases (HDACs) are a class of enzymes which act directly on Nox transcription by removing acetyl groups from histone proteins, reducing chromatin relaxation and suppressing gene transcription [64]. HDACs also have some activity on non-histone proteins (including transcription factors like AP- 1 and NF- $\mathrm{KB}$ ), indirectly suppressing gene transcription [63]. Although, and what may appear somewhat paradoxical, inhibition of HDACs reduces expression of Nox $[65,66]$. This may be in part due to hyperacetylation at Nox promotor regions, blocking the action of RNA polymerase II and c-jun (a key constituent protein unit found in AP-1) when HDAC is inhibited [64,66,67]. DNA methylation and histone modification may play a key role in the regulation of Nox [48]. DNA at the Rac1 promoter region (a key subunit of Nox1/2) undergoes methylation in response to hyperglycaemia within retinal ECs and is associated with increased Nox expression and activity [68]. Furthermore, Hussain et al. elegantly showed within a diabetic murine model that the downregulation of JunD (a negative regulator of Nox) was mediated by hypermethylation and post-translational histone methylation within the promoter region of JunD [48]. Similarly, increased histone acetylation (HAT) within the promoter region of Nox5 (with an associated increased Nox 5 activity) has been found in human atherosclerotic tissue samples [69]. Acetylation of non-histone proteins like transcription factors, may also have a key role to play in the regulation of Nox [70].

miRs are a large class of non-coding RNA that play a critical role at the post transcriptional level, by binding to complementary mRNAs at specific sequences located within the $3^{\prime}$ UTR of target mRNA, leading to transcriptional inhibition or degradation [71] miRs are found to be dysregulated in a range of disorders including cardiovascular disease, diabetes and cancer [72-77]. There is a growing body of evidence that an abundance of miRs play an important role in regulation of Nox (see recent review by Wlodarski et al. [78]). Of particular interest is miR-25.

A number of studies have investigated the relationship between miR-25 and Nox4, although with conflicting results. Early studies of miR-25 in a rat diabetes model demonstrated miR-25 downregulated Nox4 expression $[79,80]$. More recently, Liu et al. demonstrated that treating diabetic mice with an miR-25 antagomir reduced Nox4 expression; whilst inhibition of miR-25 in healthy mice led to increased blood pressure and renal dysfunction [81]. Liu et al. also observed that miR-25 was decreased in plasma from diabetic patients, and that upregulation of miR-25 in obese mice reversed diabetes induced nephropathy and reduced blood pressure by inhibiting the renin-angiotensin aldosterone system [81]. Despite clear links between miR-25 and Nox4 expression in both models of diabetes and human studies, inhibition of miR-25 in patients with heart failure has no effect on myocardial Nox4 expression-suggesting the role of miR-25 in the regulation of Nox4 may be tissue and context specific [82].

In EC specifically, miR-146a and miR-92b have both been shown to reduce Nox4 expression, $[83,84]$ whilst other miR that have been shown to downregulate Nox4 expression include miR-363-3p, miR-182, miR-99, miR-590, miR-423-5p, miR-125b, miR-29a-5p, miR-29c-3p, and miR-132-3p and miR-17 [85-92].

High-throughput screening of miRs targeting Nox2 has identified miR-106b, miR148b, miR-204 and miR-448-3p as important negative regulators of Nox2 at a gene and protein level $[93,94]$. Other negative regulators of Nox2 expression reported in the literature include: miR-320, miR-27b, miR-99, miR-125b, miR-18a, miR-210, miR-126a-5p, miR-29c, miR-17 and miR-34a [87,90-92,95-100].

Compared to Nox 2 and Nox 4 there is a smaller body of published research investigating the regulation of Nox 1 and Nox 5 by miR within the endothelium. However, miR-1264, miR-298-5p and miR-217 have been shown to reduce expression of Nox1 in vascular smooth muscle cells and macrophages [101-103]. miR-15a-3p has been shown to 
reduce Nox5 expression within human ECs [104]; whilst miR-465, miR-4321 and miR-4270 have been reported as being negative regulators of Nox 5 in the literature $[105,106]$.

\section{Oxidative Stress in Type 2 Diabetes Mellitus}

Type 2 diabetes mellitus is a disorder of metabolism and fuel homeostasis characterised by insulin resistance, with resultant hyperglycaemia [107].

Insulin resistance is associated with endothelial dysfunction [108]. Insulin stimulates the production of $\mathrm{NO}$ by acting on the insulin receptor and insulin-like growth factor 1 receptor, leading to a rapid, dose-dependent production of NO via the PI3K/Akt signalling cascade [109-111]. Akt induces phosphorylation and activation of eNOS at serine 1177, which in turn stimulates the transfer of electrons from NADPH resulting in the conversion of L-arginine to L-citrulline and the formation of NO (Figure 3) [111].

Hyperglycaemia can directly increase ROS formation by enhancing the mitochondrial electron transport chain and eNOS uncoupling $[112,113]$. Furthermore, hyperglycaemia also stimulates Nox to produce ROS, by increasing synthesis of di-acylglycerol (DAG) and activation of PKC [112]. In addition, nutrient excess in type 2 diabetes mellitus can overload the protein folding capacity of the endoplasmic reticulum (ER) resulting in the formation of $\mathrm{H}_{2} \mathrm{O}_{2}$ and $\mathrm{O}_{2}{ }^{--}$[114,115]. Hyperglycaemia also leads to the formation of advanced glycation end products (AGEs); proteins which have undergone glycosylation and which instigate EC dysfunction [116]. In murine models of diabetes, AGE also increase production of ROS by mitochondria and Nox $[117,118]$. Methylglyoxal (MGO), a highly reactive dicarbonyl compound, is a major precursor of AGE formed during glucose and fatty acid metabolism [119]. Moreover, production of MGO is regulated by Nox [120].

In addition to activation of the PI3K-Akt pathway via tyrosine kinase, insulin and IGF-1 can activate several MAPKs, including c-Jun N-terminal (JNK), extracellular signal regulated kinase 1/2 (ERK1/2) and IKB kinase (IKK). MAPKs are activated through a series of phosphorylative protein reactions dependent on the interaction of Ras with Shc adaptor protein [35]. ERK1/2, JNK and IKK can phosphorylate IRS-1 and interrupt the PI3K-Akt pathway, reducing eNOS synthesis and production of NO [121,122]. MAPK are inactivated by MAPK phosphatases [123], the action of which is inhibited by ROS [124].

Insulin resistance is associated with chronic activation of pro-inflammatory signalling pathways [125]. The mechanism underpinning this association is thought to be mediated by variety of cytokines including TNF $\alpha$, interleukin (IL)-1 $1 \beta$, IL-10 and IFN $\gamma$; all of which are found at high levels within macrophages in adipose tissue [126]. TNF $\alpha$ and IL-1 $\beta$ activate both the IKK/NF-KB and JNK signalling cascade leading to inhibition of downstream insulin signalling by serine phosphorylation of IRS-1 [126].

The MAPK pathway is thought to be pivotal in the pathophysiology of endothelial dysfunction in type 2 diabetes mellitus. Serum insulin levels increase in response to peripheral insulin resistance; however, as insulin is unable to activate the PI3K-Akt pathway it increases activation of the MAPK pathway leading to reduced production of eNOS. Moreover, increasing quantities of ROS from hyperglycaemia and hyperinsulinaemia enhance the activity of the MAPK pathway. Finally, MAPK, IFN $\gamma$, TNF- $\alpha$ and transforming growth factor (TGF)- $\beta$ all upregulate expression of Nox through the action of numerous transcription factors, increasing the production of $\mathrm{O}_{2}{ }^{\bullet-}$ and leading to a vicious, perpetuating cycle culminating in reduced production of eNOS and endothelial dysfunction $[44,45,47,54]$. 


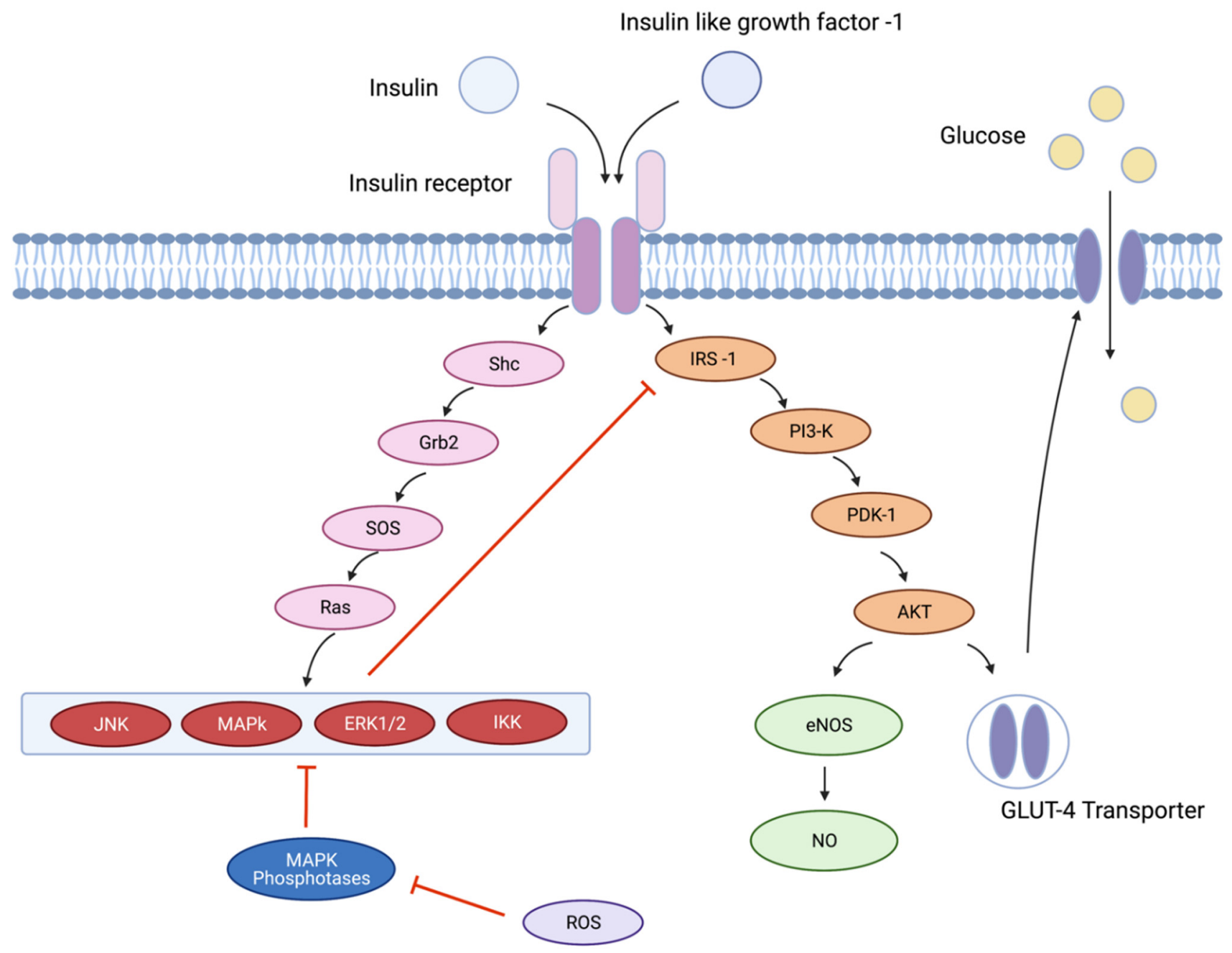

Figure 3. Insulin/Insulin like growth factor-1 signaling and insulin resistance. Insulin and insulin like growth factor-1 bind to the insulin receptor at the phospholipid bilayer of the cell resulting in activation of in several simultaneous protein cascades: Activation of insulin-receptor substrate-1 and downstream signaling via the interrupt the PI3K-Akt pathway, culminates in phosphorylation of Akt Phosphorylated Akt increases expression of eNOS leading to production of nitric oxide and brings about translocation of GLUT-4 transporters from the cytoplasm to the cell membrane allowing glucose to enter the cell. Activation of Shc and subsequent downstream signaling results in activation of ERK1/2, IKK, JNK and MAPK which phosphorylate IRS-1 and interrupt the PI3K-Akt pathway. Interruption of the PI3K-Akt pathway results in reduced entry of glucose into the cell and endothelial dysfunction. JNK, MAPK, ERK1/2 and IKK are inactivated by MAPK phosphates which is itself inhibited by ROS. Abbreviations: glucose transporter type 4 (GLUT-4), endothelial nitric oxide synthase (eNOS), extracellular signaling related kinase 1 and 2 (ERK1/2) growth factor receptor-bound protein 2 (Grb2), IKB kinase (IKK) Insulin receptor substrate 1 (IRS-1), c-Jun N-terminal (JNK), mitogen-activated protein kinase (MAPK), nitric oxide (NO), phosphoinositide 3-kinase (PI3K), phosphoinositide-dependent kinase-1 (PDK-1), reactive oxygen species (ROS), Son of Sevenless (SOS). Created with BioRender.com (accessed on 31 August 2021).

\section{Nox1 in Type 2 Diabetes Mellitus Related Endothelial Dysfunction}

Human aortic endothelial cells exposed to hyperglycaemia showed increased expression of Nox1, oxidative stress and proinflammatory markers in a Nox1-siRNA reversible manner [127]. In addition, in a murine model of atherosclerosis, deletion of NOX1 had a profound anti-atherosclerotic effect. Thus, the study suggests, Nox1-dependent oxidative stress is a promising target for diabetic vasculopathy, including atherosclerosis [127].

Excess ROS derived from Nox1 and Nox4 have been shown to contribute to diabetic retinopathy, an end-stage disease of diabetes mellitus, which threatens vision as a result of increased vascular permeability and neovascularisation [128]. Inhibition of Nox1/4 in 
bovine endothelial cells reduces the high glucose induced oxidative stress, angiogenic and inflammatory markers, indicated the potential of Nox1 and Nox4 inhibition in reducing the vision damage associated with diabetic retinopathy [129].

The importance of Nox1 in diabetic nephropathy, another end-stage disease of diabetes mellitus, has been demonstrated using a rodent model of genetic obesity. In obese zucker rats, Nox1-derived $\mathrm{O}_{2}{ }^{\bullet-}$ was the main cause of renal endothelial dysfunction, highlighting the need to identify and target the specific Nox isoforms involved in tissue-specific metabolic disease [130].

\section{Nox2 in Type 2 Diabetes Mellitus-Related Endothelial Dysfunction}

In vivo studies of whole body and EC specific insulin resistance using gene-modified mice have offered fascinating insights into the role of Nox2 in the pathophysiology of type 2 diabetes mellitus and its cardiovascular complications [16,131-135].

High fat feeding, with resultant whole body insulin resistance and glucose intolerance, is an established murine model for type 2 diabetes mellitus, and has been shown to increase Nox2 protein expression and superoxide production [16]. Further to this, although NOX2$\mathrm{KO}$ mice fed a high fat diet still demonstrated insulin resistance compared to NOX2-KO mice on a standard diet, the magnitude of insulin resistance was significantly smaller, and the production of $\mathrm{O}_{2}{ }^{\bullet-}$ was no longer increased, implying that Nox2 has a pivotal role in the insulin resistance and ROS production associated with type 2 diabetes [136]. Akt phosphorylation and glucose transporter 4 (GLUT4) translocation were decreased in skeletal muscle of wild type mice fed a high fat diet but this effect was not seen in NOX2KO mice [136]. This suggests that deletion of NOX2 leads to increased sensitivity to insulin, whilst protecting against the detrimental effects of high fat diet through Nox2-dependent regulation of Akt phosphorylation and GLUT4 expression [136].

The effects of EC specific insulin resistance have been assessed using a transgenic mouse with endothelial overexpression of an insulin resistant mutant IR (ESMIRO). Alongside their disrupted EC specific insulin signalling, ESMIRO mice demonstrated increased expression of EC Nox2 and Nox4 [13]. Subsequent work has gone on to assess the effects of inhibiting Nox2 in this model and in mice with insulin resistance due to haploinsufficiency of the IR at the whole-body level $\left(\mathrm{IR}^{+/-}\right)$. Nox 2 dependent $\mathrm{O}_{2}{ }^{\bullet-}$ production was significantly increased in pulmonary EC from ESMIRO and $\mathrm{IR}^{+/-}$mice [16]. Furthermore, knockdown of NOX2 in pulmonary EC of ESMIRO and $\mathrm{IR}^{+/-}$mice led to significant reduction of $\mathrm{O}_{2}{ }^{\bullet-}$, confirming Nox2 as an important intermediary in the ROS-induced endothelial dysfunction associated with insulin resistance [16]. By crossing the ESMIRO mice with NOX2 holoinsufficient mice (Nox $2^{\mathrm{y} /-}$ ), we were able to study the effect of chronic Nox2 deficiency in the setting of insulin resistance. Basal production of $\mathrm{O}_{2}{ }^{\bullet-}$ within pulmonary EC of ESMIRO/Nox $2^{\mathrm{y} /-}$ mice was reduced compared to that of ESMIRO mice alone, highlighting that Nox2 is a vital intermediary in the production of ROS in insulin resistance, and confirming that there is no adequate compensatory mechanism for increasing ROS production in the setting of insulin resistance if Nox2 is deficient [16].

Interestingly, in the setting of enhanced EC insulin sensitivity, we have been able to demonstrate increased Nox2 dependent $\mathrm{O}_{2}{ }^{\bullet-}$ release and reduced NO bioavailability. In fact, genetically enhancing endothelial insulin sensitivity results in a contradictory decrease in endothelial function, a change that is driven by an increase in Nox2-dependent oxidative stress and a PYK2-dependent reduction in eNOS activity [15]. This adds further weight to the idea that relationship between ROS production and EC function is likely bell-shaped.

Given that endothelial dysfunction increases the likelihood of atherosclerosis development, we have investigated the relationship between Nox2 and atherosclerosis development using apolipoprotein E-deficient ESMIRO mice (ESMIRO/ $\mathrm{ApoE}^{-/-}$) with genetic and pharmacological inhibition of Nox2 [18]. ESMIRO/ $\mathrm{ApoE}^{-/-}$mice with germline knockdown of NOX2 $\left(\mathrm{ESMIRO} / \mathrm{ApoE}^{-/-} / \mathrm{Nox}^{-/ \mathrm{y}}\right.$ ) had reduced $\mathrm{O}_{2}{ }^{\bullet-}$ generation within pulmonary EC and improved aortic relaxation to acetylcholine compared to their $\mathrm{ESMIRO} / \mathrm{ApoE}^{-/-} / \mathrm{Nox}^{+/ \mathrm{y}}$ littermates [18]. In addition, $\mathrm{ESMIRO} / \mathrm{ApoE}^{-/-} / \mathrm{Nox}^{-/ y}$ mice had increased thoraco-abdominal 
aortic lipid deposition, and multiple foci of atherosclerosis associated elastin fragmentation in the aortic sinus. These changes were accompanied by increased aortic expression of ICAM-1 and VCAM-1 [18]. However, inhibition of Nox2 with gp91dstat, whilst also reducing pulmonary EC $\mathrm{O}_{2}{ }^{\bullet-}$ reduced aortic atherosclerosis and elastin fragmentation in ESMIRO/ApoE ${ }^{-/-}$mice [18] Once again, it is clear that the relationship between insulin resistance and Nox 2 dependent $\mathrm{O}_{2}{ }^{\bullet-}$ release is far from linear. The divergent effects of genetic versus pharmacological inhibition of Nox2 are likely to be complex and may be related to the duration of Nox2 inhibition.

Within the microvasculature, Nox2-derived ROS is fundamental in the development of diabetes induced retinal inflammation and diabetic retinopathy $[137,138]$. Deletion of the NOX2 gene reduces ROS production, VEGF and ICAM-1 expression, and the breakdown of the blood-retinal barrier [137,138]. Furthermore, diabetes increases Nox2 generated ROS within bovine retinal premature EC, inducing EC senescence by increases in expression and activity of arginase- 1 (which decreases NO bioavailability). Inhibition of Nox 2 in bovine retinal EC and deletion of NOX2 in mice ameliorates premature EC senescence by limiting the activity of arginase-1 [139].

\section{Nox4 and Endothelial Function}

Initially, Nox4 was thought to also play a pathological role within the endothelium [140]. Studies using siRNA within cultured EC implicated Nox4 as being responsible for causing oxidative damage within the endothelium, reducing EC replicative potential and causing endothelial dysfunction [140]. Wang et al. demonstrated that hyperglycaemia increased protein expression of Nox4 within human aortic EC; with associated increased production of ROS, IL-6 and IL-8 [83]. Nox4 activity has also been shown to be increased in the serum of patients with type 2 diabetes mellitus [141]. More recently, however, in a unique murine model of EC insulin resistance with whole body insulin sensitivity, we demonstrated reduced EC expression of Nox2 and miR-25, but increased expression of Nox4 and an associated increased production of $\mathrm{H}_{2} \mathrm{O}_{2}$ [142]. Furthermore, transgenic mice with endothelial targeted overexpression of $\mathrm{NOX} 4$ had increased $\mathrm{H}_{2} \mathrm{O}_{2}$ production and $\mathrm{H}_{2} \mathrm{O}_{2}$-induced hyperpolarization (without affecting endothelial $\mathrm{NO}$ bioactivity) within their coronary microvascular ECs, resulting in significantly greater acetylcholine- or histamine-induced vasodilatation compared to their wild type littermates [143].

Moreover, data from $\mathrm{KO}$ mice suggest that Nox4 might offer further protective benefits within the endothelium by promoting angiogenesis [144,145]. EC migration and proliferation is inhibited when the NOX4 gene is silenced; whilst EC with overexpression of NOX4 have increased angiogenesis in vitro $[146,147]$. Deletion of $\mathrm{NOX} 4$ in mice reduces $\mathrm{H}_{2} \mathrm{O}_{2}$ production and inhibits EC tube formation. Moreover, the addition of low concentrations of $\mathrm{H}_{2} \mathrm{O}_{2}$ restores EC tube formation-highlighting the important role of Nox4 derived $\mathrm{H}_{2} \mathrm{O}_{2}$ in endothelial function [145]. Addition of cord blood-derived endothelial colony-forming cells, which have overexpression of NOX4, to an ischaemic murine hindlimb model upregulates several angiogenic factors and promotes post-ischaemic revascularisation [148]. Nox4 also appears to have anti-atherosclerotic properties [149]. Deletion of NOX4 in $\mathrm{ApoE}^{-/-}$ mice fed a high fat diet accelerated atherosclerosis development and resulted in greater disease development after partial carotid artery ligation [149]. Furthermore, genetic deletion of NOX4 in a low-density lipoprotein receptor (Ldlr) knockout mouse model reduced the vasodilatory capacity of the endothelium and increased atherosclerotic plaque burden, as a result of reduced $\mathrm{H}_{2} \mathrm{O}_{2}$ production [150].

Physiologically, Nox4 appears to play a significant role in regulating the metabolic and vascular adaptions needed during exercise [151,152]. Nox4-deficient mice had impaired glucose and fatty acid oxidation in response to acute exercise. Furthermore, following a chronic exercise regime, NOX4-deficient mice had worse exercise capacity (measured by a reduced time to exhaustion) and reduced activity of skeletal muscle citrate synthase and beta-hydroxyacyl-coA dehydrogrenase (important enzymes involved in mitochondrial metabolism) compared to their wild-type litter mates [151]. Access to an exercise wheel prevented endothelial dysfunction in wild-type, but not Nox4 $4^{-/-}$deficient mice fed a high 
fat diet [152]. Exercise of wild type mice resulted in increased $\mathrm{H}_{2} \mathrm{O}_{2}$ release in the aorta with increased phosphorylation of Akt and activation of eNOS, whereas both $\mathrm{H}_{2} \mathrm{O}_{2}$ release and phosphorylation of Akt were reduced in aortas of Nox4 $4^{-/-}$mice. In addition, knockout of NOX4 prevented the normal exercise-induced increase in mitochondrial capacity as measured by exercise-induced citrate synthase activity and mitochondria mass [152]. This all suggests that Nox4 has a key mechanistic role in modulating the protective effects of physical activity on endothelial function.

\section{Nox 5 in Type 2 Diabetes Mellitus Related Endothelial Dysfunction}

Nox5 is expressed in human ECs and is of growing interest in endothelial disease/dysfunction, due to its promotion of EC proliferation [153]. It is absent from rodents, and thus is not easily studied in vivo, despite being expressed by humans and other higher mammals [154]. There does, however, seem to be emerging evidence that Nox5 plays a critical role in a range of vascular diseases, including those associated with diabetes (review in [155]).

A recent sophisticated study, in which transgenic mice with inducible human Nox5 expressed in ECs were generated, demonstrated increased retinal vascular permeability and neovascularisation compared with their wild-type litter mates. In bovine retinal ECs, which express Nox5 (alongside Nox1 and 4), Nox5-siRNA also reduced high glucose induced oxidative stress, angiogenic and inflammatory markers, adding Nox 5 inhibition to the potential list of therapeutic targets for reducing the visual damage associated with diabetic retinopathy [129].

A similar murine model, with increased expression of human Nox5 in the endothelium, has shown age-related severe systolic hypertension, and impaired endothelium-dependent vasodilation, as a result of Nox5-induced uncoupling of eNOS [156]. Further work within a conditional endothelial NOX5 knock-in mouse, has identified a role for Nox5 in the response to ischaemia as a result of myocardial infarction, with evidence that Nox5-derived ROS may modulate the COX-2 and $\mathrm{PGE}_{2}$ axis in EC. [157].

\section{Therapeutic Targeting of Nox}

Initially it was thought that natural antioxidants (such as vitamin C, vitamin E, coenzyme $Q$ amongst many others) may have a therapeutic role in reducing oxidative stress by targeting Nox [158]. These antioxidants have a range of actions and target a variety of subunits within the Nox complex [158]. However, the results of large-scale clinical trials using these antioxidants have been disappointing, showing no significant mortality benefit and for some agents (like vitamin A, vitamin E and beta-carotene) a tendency to cause harm [159].

More recently, specific Nox inhibitors have been developed, the full details of which are outside the scope of this review (see review in [160]). Problems of non-selectivity remain for many of these agents, due to their mechanism of action targeting protein subunits shared by several Nox isoforms [160]. NOX2ds-tat peptide is an exception to this rule, which binds to the p47phox subunit and is selective for Nox2. However, the low bioavailability of peptides limits its use within in vivo studies and as a therapeutic agent in humans [161].

GKT137831 (a dual Nox1/Nox4 inhibitor) was another Nox inhibitor of interest. [162] However, a clinical trial of GKT137831 vs. placebo in patients with type 2 diabetes mellitus related kidney disease and albuminuria failed to meet its primary endpoint of reduction in albuminuria, (https:/ / www.businesswire.com/news/home/20150909005080/en/ Genkyotex-Announces-Top-Line-Results-of-Phase-2-Clinical-Program (accessed on 31 August 2021)) the results of which have not been fully published. A phase II trial of GKT137831 in T1DM is ongoing [163].

Targeting the epigenetic machinery which regulate Nox transcription may provide a future avenue for therapeutic research $[67,164]$. Drugs inhibiting specific miRs involved in diabetes and endothelial dysfunction are being developed. These drugs are delivered 
using a variety of methods including: nanoparticles, dendrimers, aptamers or within liposomes [164]. Aptamers (small oligonucleotides which bind to a specific target molecule) are of specific interest as they have the essential ability to target a particular miRNA within a specific cell type [164]. Phase 2 trials of miR inhibitors are ongoing, albeit outside the field of diabetes. However, research in this area is still in its early stages and no therapeutic agent targeting miR within this field is currently close to coming to market [165].

\section{Conclusions}

Oxidative stress driven by ROS is a fundamental process in the pathogenesis of type 2 diabetes mellitus. Whilst generation of low concentrations of ROS are indispensable for normal cellular function, excess $\mathrm{O}_{2}{ }^{\bullet-}$ potentiates endothelial dysfunction and progression of the cardiovascular complications of type 2 diabetes mellitus. Nox1, Nox2 and Nox5 generate $\mathrm{O}_{2}{ }^{\bullet-}$ and are ubiquitously harmful; whilst Nox4 generates $\mathrm{H}_{2} \mathrm{O}_{2}$ - which plays a more physiological role as a key signalling molecule. Whilst all Nox isoforms may be attractive targets for the development of novel therapeutic agents, it is clear that Nox expression is complex and likely tissue specific. Careful thought is therefore needed when devising new treatments targeting Nox, and its downstream effects. Manipulation of miR may overcome some of these issues in drug development. However, research in this area is still in its relative infancy.

Author Contributions: O.I.B., K.I.B. and M.T.K. were all responsible for writing the manuscript and critical revisions prior to submission. All authors have read and agreed to the published version of the manuscript.

Funding: MTK holds a British Heart Foundation Chair in Cardiovascular and Diabetes Research $(\mathrm{CH} / 13 / 1 / 30086)$. OIB is funded by the National Institute for Health Research (ACF-2019-03-003).

Acknowledgments: All figures were created with Biorender.com (accessed on 31 August 2021).

Conflicts of Interest: The authors declare no conflict of interest.

\section{References}

1. Sies, H. Oxidative stress: A concept in redox biology and medicine. Redox Biol. 2015, 4, 180-183. [CrossRef]

2. Rhee, S.; Hyun, A.; Dongmin, K. The Role of Peroxiredoxins in the Transduction of H2O2Signals. Antioxid Redox Signal. Antioxid. Redox Signal. 2018, 28, 537-557. [CrossRef]

3. Matthijnssens, J.; Ciarlet, M.; Rahman, M.; Attoui, H.; Estes, M.K.; Gentsch, J.R.; Iturriza-gómara, M.; Kirkwood, C.; Mertens, P.P.C.; Nakagomi, O.; et al. Redox-based regulation of signal transduction: Principles, pitfalls, and promises. Free Radic. Biol. Med. 2009, 153, 1621-1629.

4. Sies, H. Hydrogen peroxide as a central redox signaling molecule in physiological oxidative stress: Oxidative eustress. Redox Biol. 2017, 11, 613-619. [CrossRef] [PubMed]

5. Elbatreek, M.H.; Pachado, M.P.; Cuadrado, A.; Jandeleit-Dahm, K.; Schmidt, H.H.H.W. Reactive Oxygen Comes of Age: Mechanism-Based Therapy of Diabetic End-Organ Damage. Trends Endocrinol. Metab. 2019, 30, 312-327. [CrossRef] [PubMed]

6. Drummond, G.R.; Sobey, C.G. Endothelial NADPH oxidases: Which NOX to target in vascular disease? Trends Endocrinol. Metab. 2014, 25, 452-463. [CrossRef] [PubMed]

7. Bedard, K.; Krause, K.H. The NOX family of ROS-generating NADPH oxidases: Physiology and pathophysiology. Physiol. Rev. 2007, 87, 245-313. [CrossRef]

8. Serrander, L.; Cartier, L.; Bedard, K.; Banfi, B.; Lardy, B.; Plastre, O.; Sienkiewicz, A.; Fórró, L.; Schlegel, W.; Krause, K.H. NOX4 activity is determined by mRNA levels and reveals a unique pattern of ROS generation. Biochem. J. 2007, 406, 105-114. [CrossRef] [PubMed]

9. Takac, I.; Schröder, K.; Zhang, L.; Lardy, B.; Anilkumar, N.; Lambeth, J.D.; Shah, A.M.; Morel, F.; Brandes, R.P. The E-loop is involved in hydrogen peroxide formation by the NADPH oxidase Nox4. J. Biol. Chem. 2011, 286, 13304-13313. [CrossRef] [PubMed]

10. Imrie, H.; Abbas, A.; Kearney, M.T. Insulin resistance, lipotoxicity and endothelial dysfunction. Biochim. Biophys. Acta 2010, 1801, 320-326. [CrossRef] [PubMed]

11. Diabetes Genetics Replication and Meta-analysis Consortium (DIAGRAM). Large-scale association analysis provides insights into the genetic architecture and pathophysiology of type 2 diabetes. Nat. Genet. 2012, 44, 981-990. [CrossRef] [PubMed]

12. Jesmin; Rashid, M.S.M.; Jamil, H.; Hontecillas, R.; Bassaganya-Riera, J. Gene regulatory network reveals oxidative stress as the underlying molecular mechanism of type 2 diabetes and hypertension. BMC Med. Genom. 2010, 3. [CrossRef] 
13. Duncan, E.R.; Crossey, P.A.; Walker, S.; Anilkumar, N.; Poston, L.; Douglas, G.; Ezzat, V.A.; Wheatcroft, S.B.; Shah, A.M.; Kearney, M.T. Effect of endothelium-specific insulin resistance on endothelial function in vivo. Diabetes 2008, 57, 3307-3314. [CrossRef] [PubMed]

14. Duncan, E.R.; Walker, S.J.; Ezzat, V.A.; Wheatcroft, S.B.; Li, J.M.; Shah, A.M.; Kearney, M.T. Accelerated endothelial dysfunction in mild prediabetic insulin resistance: The early role of reactive oxygen species. Am. J. Physiol.-Endocrinol. Metab. 2007, 293, 1311-1319. [CrossRef] [PubMed]

15. Viswambharan, H.; Yuldasheva, N.Y.; Sengupta, A.; Imrie, H.; Gage, M.C.; Haywood, N.; Walker, A.M.N.; Skromna, A.; Makova N.; Galloway, S.; et al. Selective Enhancement of Insulin Sensitivity in the Endothelium in Vivo Reveals a Novel Proatherosclerotic Signaling Loop. Circ. Res. 2017, 120, 784-798. [CrossRef]

16. Sukumar, P.; Viswambharan, H.; Imrie, H.; Cubbon, R.M.; Yuldasheva, N.; Gage, M.; Galloway, S.; Skromna, A.; Kandavelu, P.; Santos, C.X.; et al. Nox2 NADPH oxidase has a critical role in insulin resistance-related endothelial cell dysfunction. Diabetes 2013, 62, 2130-2134. [CrossRef]

17. Silver, A.E.; Beske, S.D.; Christou, D.D.; Donato, A.J.; Moreau, K.L.; Eskurza, I.; Gates, P.E.; Seals, D.R. Overweight and obese humans demonstrate increased vascular endothelial NAD $(\mathrm{P}) \mathrm{H}$ oxidase-p47phox expression and evidence of endothelial oxidative stress. Circulation 2007, 115, 627-637. [CrossRef]

18. Maqbool, A.; Watt, N.T.; Haywood, N.; Viswambharan, H.; Skromna, A.; Makava, N.; Visnagri, A.; Shawer, H.M.; Bridge, K.; Muminov, S.K.; et al. Divergent effects of genetic and pharmacological inhibition of Nox2 NADPH oxidase on insulin resistance-related vascular damage. Am. J. Physiol. Cell Physiol. 2021, 319, 64-74. [CrossRef]

19. Bjelakovic, G.; Nikolova, D.; Gluud, L.; Simonetti, R.; Gluud, C. Mortality in randomized trials of antioxidant supplements for primary and secondary prevention: Systematic review and meta-analysis. JAMA 2007, 297, 842-857. [CrossRef]

20. Trujillo, M.; Alvarez, M.; Peluffo, G.; Freeman, B.; Radi, R. Xanthine Oxidase-mediated Decomposition of S-Nitrosothiols. J. Biol. Chem. 1998, 273, 7828-7834. [CrossRef]

21. Landmesser, U.; Dikalov, S.; Price, S.; McCann, L.; Fukai, T.; Holland, S.; Mitch, W.; Harrison, D. Oxidation of tetrahydrobiopterin leads to uncoupling of endothelial cell nitric oxide synthase in hypertension. J. Clin. Investig. 2003, 111, 1201-1209. [CrossRef]

22. Zhao, R.; Jiang, S.; Zhang, L.; Yu, Z. Mitochondrial electron transport chain, ROS generation and uncoupling (Review). Int. J. Mol. Med. 2019, 44, 3-15. [CrossRef]

23. Battelli, M.G.; Polito, L.; Bortolotti, M.; Bolognesi, A. Xanthine oxidoreductase-derived reactive species: Physiological and pathological effects. Oxid. Med. Cell. Longev. 2016, 2016, 3527579. [CrossRef]

24. Gebhart, V.; Reiß, K.; Kollau, A.; Mayer, B.; Gorren, A.C.F. Site and mechanism of uncoupling of nitric-oxide synthase: Uncoupling by monomerization and other misconceptions. Nitric. Oxide.-Biol. Chem. 2019, 89, 14-21. [CrossRef]

25. Kearney, M.T.; Duncan, E.R.; Kahn, M.; Wheatcroft, S.B. Insulin resistance and endothelial cell dysfunction: Studies in mammalian models. Exp. Physiol. 2008, 93, 158-163. [CrossRef] [PubMed]

26. Förstermann, U.; Sessa, W.C. Nitric oxide synthases: Regulation and function. Eur. Heart J. 2012, 33, 829-837. [CrossRef] [PubMed]

27. Radi, R. Oxygen radicals, nitric oxide, and peroxynitrite: Redox pathways in molecular medicine. Proc. Natl. Acad. Sci. USA 2018, 115, 5839-5848. [CrossRef] [PubMed]

28. Heiss, E.; Dirsch, V. Regulation of eNOS Enzyme Activity by Posttranslational Modification. Curr. Pharm. Des. 2014, 20, 3503-3513. [CrossRef] [PubMed]

29. Zhao, S.; Cheng, C.K.; Zhang, C.-L.; Huang, Y. Interplay between Oxidative Stress, Cyclooxygenases, and Prostanoids in Cardiovascular Diseases. Antioxid. Redox Signal. 2021, 34, 784-799. [CrossRef]

30. King, L.S.; Fukushima, M.; Banerjee, M.; Kang, K.H.; Newman, J.H.; Biaggioni, I. Pulmonary Vascular Effects of Prostaglandin D2, but Not Its Systemic Vascular or Airway Effects, Are Mediated through Thromboxane Receptor Activation. Circ. Res. 1991, 68, 352-358. [CrossRef]

31. Hernanz, R.; Briones, A.M.; Salaices, M.; Alonso, M.J. New Roles for Old Pathways? A Circuitous Relationship between Reactive Oxygen Species and Cyclo-Oxygenase in Hypertension. Clin. Sci. 2014, 126, 111-121. [CrossRef]

32. Brown, D.; Griendling, K. Nox proteins in signal transduction. Free Radic. Biol. Med. 2009, 47, 1239-1253. [CrossRef] [PubMed]

33. Burtenshaw, D.; Hakimjavadi, R.; Redmond, E.; Cahill, P. Nox, Reactive oxygen species and regulation of vascular cell fate. Antioxidants 2017, 6, 90. [CrossRef]

34. Thomas, S.; Kotamraju, S.; Zielonka, J.; Harder, D.R.; Kalyanaraman, B. Hydrogen peroxide induces nitric oxide and proteosome activity in endothelial cells: A bell-shaped signaling response. Free Radic. Biol. Med. 2007, 42, 1049-1061. [CrossRef] [PubMed]

35. Schmid, E.; Hotz-Wagenblatt, A.; Hacj, V.; Dröge, W. Phosphorylation of the insulin receptor kinase by phosphocreatine in combination with hydrogen peroxide: The structural basis of redox priming. FASEB J. 1999, 13, 1491-1500. [CrossRef] [PubMed]

36. $\mathrm{Hu}, \mathrm{Z}$;; Chen, J.; Wei, Q.; Xia, Y. Bidirectional actions of hydrogen peroxide on endothelial nitric-oxide synthase phosphorylation and function: Co-commitment and interplay of Akt and AMPK. J. Biol. Chem. 2008, 283, 25256-25263. [CrossRef]

37. Cai, H. Hydrogen peroxide regulation of endothelial function: Origins, mechanisms, and consequences. Cardiovasc. Res. 2005, 68, 26-36. [CrossRef]

38. Bánfi, B.; Tirone, F.; Durussel, I.; Knisz, J.; Moskwa, P.; Molnár, G.Z.; Krause, K.-H.; Cox, J.A. Mechanism of Ca ${ }^{2+}$ Activation of the NADPH Oxidase 5 (NOX5). J. Biol. Chem. 2004, 279, 18583-18591. [CrossRef]

39. Namgaladze, D.; Shcherbyna, I.; Kienhöfer, J.; Hofer, H.W.; Ullrich, V. Superoxide targets calcineurin signaling in vascular endothelium. Biochem. Biophys. Res. Commun. 2005, 334, 1061-1067. [CrossRef] [PubMed] 
40. Förstermann, U. Janus-faced role of endothelial NO synthase in vascular disease: Uncoupling of oxygen reduction from NO synthesis and its pharmacological reversal. Biol. Chem. 2006, 387, 1521-1533. [CrossRef] [PubMed]

41. Pacher, P.; Beckman, J.S.; Liaudet, L. Nitric oxide and peroxynitrite in health and disease. Physiol. Rev. 2007, 87, 315-424. [CrossRef] [PubMed]

42. Watt, N.T.; Gage, M.C.; Patel, P.A.; Viswambharan, H.; Sukumar, P.; Galloway, S.; Yuldasheva, N.Y.; Imrie, H.; Walker, A.M.N.; Griffin, K.J.; et al. Endothelial SHIP2 Suppresses Nox2 NADPH Oxidase-Dependent Vascular Oxidative Stress, Endothelial Dysfunction, and Systemic Insulin Resistance. Diabetes 2017, 66, 2808-2821. [CrossRef]

43. Chen, F.; Haigh, S.; Barman, S.; Fulton, D.J.R. From form to function: The role of Nox4 in the cardiovascular system. Front. Physiol. 2012, 3, 412. [CrossRef]

44. Lou, Z.; Wang, A.P.; Duan, X.M.; Hu, G.H.; Song, G.L.; Zuo, M.L.; Yang, Z.B. Upregulation of NOX2 and NOX4 Mediated by TGF- $\beta$ Signaling Pathway Exacerbates Cerebral Ischemia/Reperfusion Oxidative Stress Injury. Cell. Physiol. Biochem. 2018, 46, 2103-2113. [CrossRef] [PubMed]

45. Manea, A.; Manea, S.A.; Gafencu, A.V.; Raicu, M.; Simionescu, M. AP-1-dependent transcriptional regulation of NADPH oxidase in human aortic smooth muscle cells: Role of p22phox subunit. Arterioscler. Thromb. Vasc. Biol. 2008, 28, 878-885. [CrossRef]

46. Wingler, K.; Wünsch, S.; Kreutz, R.; Rothermund, L.; Paul, M.; Schmidt, H.H.H.W. Upregulation of the vascular NAD(P)Hoxidase isoforms Nox1 and Nox4 by the renin-angiotensin system in vitro and in vivo. Free Radic. Biol. Med. 2001, 31, 1456-1464. [CrossRef]

47. Basuroy, S.; Bhattacharya, S.; Leffler, C.W.; Parfenova, H. Nox4 NADPH oxidase mediates oxidative stress and apoptosis caused by TNF- $\alpha$ in cerebral vascular endothelial cells. Am. J. Physiol. Cell Physiol. 2009, 296, 422-432. [CrossRef]

48. Hussain, S.; Khan, A.W.; Akhmedov, A.; Suades, R.; Costantino, S.; Paneni, F.; Caidahl, K.; Mohammed, S.A.; Hage, C.; Gkolfos, C.; et al. Hyperglycemia Induces Myocardial Dysfunction via Epigenetic Regulation of JunD. Circ. Res. 2020, 1261-1273. [CrossRef]

49. Hwang, J.; Kleinhenz, D.J.; Lassègue, B.; Griendling, K.K.; Dikalov, S.; Hart, C.M. Peroxisome Proliferator-Activated Receptor- $\gamma$ Ligands Regulate Endothelial Membrane Superoxide Production. Am. J. Physiol. Cell. Physiol. 2005, 288, C899-C905. [CrossRef] [PubMed]

50. Manea, S.A.; Constantin, A.; Manda, G.; Sasson, S.; Manea, A. Regulation of Nox enzymes expression in vascular pathophysiology: Focusing on transcription factors and epigenetic mechanisms. Redox. Biol. 2015, 5, 358-366. [CrossRef]

51. Manea, A.; Tanase, L.I.; Raicu, M.; Simionescu, M. Transcriptional Regulation of NADPH Oxidase Isoforms, Nox1 and Nox4, by Nuclear Factor-KB in Human Aortic Smooth Muscle Cells. Biochem. Biophys. Res. Commun. 2010, 396, 901-917. [CrossRef]

52. Katsuyama, M.; Fan, C.; Arakawa, N.; Nishinaka, T.; Miyagishi, M.; Taira, K.; Yabe-Nishimura, C. Essential Role of ATF-1 in Induction of NOX1, a Catalytic Subunit of NADPH Oxidase: Involvement of Mitochondrial Respiratory Chain. Biochemical. J. 2005, 386, 255-261. [CrossRef] [PubMed]

53. Katsuyama, M.; Fan, C.; Yabe-Nishimura, C. NADPH Oxidase Is Involved in Prostaglandin F2 $\alpha$-Induced Hypertrophy of Vascular Smooth Muscle Cells. J. Biol. Chem. 2002, 277, 13438-13442. [CrossRef] [PubMed]

54. Kuwano, Y.; Kawahara, T.; Yamamoto, H.; Teshima-Kondo, S.; Tominaga, K.; Masuda, K.; Kishi, K.; Morita, K.; Rokutan, K. Interferon-gamma activates transcription of NADPH oxidase 1 gene and upregulates production of superoxide anion by human large intestinal epithelial cells. Am. J. Physiol. Cell Physiol. 2006, 290, C433-C443. [CrossRef] [PubMed]

55. Eklund, E.A.; Kakar, R. Recruitment of CREB-binding protein by PU.1, IFN-regulatory factor-1, and the IFN consensus sequencebinding protein is necessary for IFN- $\gamma$ - induced p67(phox) and gp91(phox) expression. J. Immunol. 1999, 163, 6095-6105. [PubMed]

56. Manea, S.; Todirita, A.; Raicu, M.; Manea, A. C/EBP Transcription Factors Regulate NADPH Oxidase in Human Aortic Smooth Muscle Cells. J. Cell. Mol. Med. 2014, 18, 1467-1477. [CrossRef] [PubMed]

57. Lassègue, B.; Sorescu, D.; Szöcs, K.; Yin, Q.Q.; Akers, M.; Zhang, Y.; Grant, S.L.; Lambeth, J.D.; Griendling, K.K. Novel gp91phox homologues in vascular smooth muscle cells: Nox1 mediates angiotensin II-induced superoxide formation and redox-sensitive signaling pathways. Circ. Res. 2001, 88, 888-894. [CrossRef]

58. Byrne, J.A.; Grieve, D.J.; Bendall, J.K.; Li, J.M.; Gove, C.; Lambeth, J.D.; Cave, A.C.; Shah, A.M. Contrasting Roles of NADPH Oxidase Isoforms in Pressure-Overload Versus Angiotensin II-Induced Cardiac Hypertrophy. Circ. Res. 2003, 93, 802-804. [CrossRef]

59. Albadrani, M.; Seth, R.K.; Sarkar, S.; Kimono, D.; Mondal, A.; Bose, D.; Porter, D.E.; Scott, G.I.; Brooks, B.; Raychoudhury, S.; et al. Exogenous PP2A inhibitor exacerbates the progression of nonalcoholic fatty liver disease via NOX2-dependent activation of miR21. Am. J. Physiol. Gastrointest. Liver Physiol. 2019, 317, 408-428. [CrossRef]

60. Laurindo, F.R.M.; Araujo, T.L.S.; Abrahão, T.B. Nox NADPH oxidases and the endoplasmic reticulum. Antioxid. Redox Signal. 2014, 20, 2755-2775. [CrossRef]

61. Pedruzzi, E.; Guichard, C.; Ollivier, V.; Driss, F.; Fay, M.; Prunet, C.; Marie, J.-C.; Pouzet, C.; Samadi, M.; Elbim, C.; et al. NAD(P)H Oxidase Nox-4 Mediates 7-Ketocholesterol-Induced Endoplasmic Reticulum Stress and Apoptosis in Human Aortic Smooth Muscle Cells. Mol. Cell. Biol. 2004, 24, 10703-10717. [CrossRef] [PubMed]

62. Pandey, D.; Patel, A.; Patel, V.; Chen, F.; Qian, J.; Wang, Y.; Barman, S.A.; Venema, R.C.; Stepp, D.W.; Daniel Rudic, R.; et al. Expression and Functional Significance of NADPH Oxidase 5 (Nox5) and Its Splice Variants in Human Blood Vessels. Am. J. Physiol. Heart Circ. Physiol. 2012, 302, 1919-1928. [CrossRef] 
63. Rosa-Garrido, M.; Chapski, D.J.; Vondriska, T.M. Epigenomes in Cardiovascular Disease. Circ. Res. 2018, $122,1586-1607$. [CrossRef]

64. Pons, D.; Jukema, J.W. Epigenetic histone acetylation modifiers in vascular remodeling-New targets for therapy in cardiovascular disease. Eur. Heart J. 2009, 30, 266-277. [CrossRef]

65. Manea, S.-A.; Antonescu, M.-L.; Fenyo, I.M.; Raicu, M.; Simionescu, M.; Manea, A. Epigenetic Regulation of Vascular NADPH Oxidase Expression and Reactive Oxygen Species Production by Histone Deacetylase-Dependent Mechanisms in Experimental Diabetes. Redox Biol. 2018, 16, 332-343. [CrossRef]

66. Siuda, D.; Zechner, U.; El Hajj, N.; Prawitt, D.; Langer, D.; Xia, N.; Horke, S.; Pautz, A.; Kleinert, H.; Förstermann, U.; et al Transcriptional regulation of Nox4 by histone deacetylases in human endothelial cells. Basic Res. Cardiol. 2012, 107, 283. [CrossRef]

67. Chen, F.; Li, X.; Aquadro, E.; Haigh, S.; Zhou, J.; Stepp, D.W.; Weintraub, N.L.; Barman, S.A.; Fulton, D.J.R. Inhibition of Histone Deacetylase Reduces Transcription of NADPH Oxidases and ROS Production and Ameliorates Pulmonary Arterial Hypertension. Free Radic. Biol. Med. 2016, 99, 167-178. [CrossRef]

68. Duraisamy, A.J.; Mishra, M.; Kowluru, A.; Kowluru, R.A. Epigenetics and Regulation of Oxidative Stress in Diabetic Retinopathy. Investig. Ophthalmol. Vis. Sci. 2018, 59, 4831-4840. [CrossRef]

69. Vlad, M.-L.; Manea, S.-A.; Lazar, A.-G.; Raicu, M.; Muresian, H.; Simionescu, M.; Manea, A. Histone Acetyltransferase-Dependent Pathways Mediate Upregulation of NADPH Oxidase 5 in Human Macrophages under Inflammatory Conditions: A Potential Mechanism of Reactive Oxygen Species Overproduction in Atherosclerosis. Oxid. Med. Cell. Longev. 2019, $2019,3201062$. [CrossRef]

70. Zarzuelo, M.J.; López-Sepúlveda, R.; Sánchez, M.; Romero, M.; Gómez-Guzmán, M.; Ungvary, Z.; Pérez-Vizcaíno, F.; Jiménez, R.; Duarte, J. SIRT1 Inhibits NADPH Oxidase Activation and Protects Endothelial Function in the Rat Aorta: Implications for Vascular Aging. Biochem. Pharmacol. 2013, 85, 1288-1296. [CrossRef]

71. Ling, H.; Fabbri, M.; Calin, G.A. MicroRNAs and Other Non-Coding RNAs as Targets for Anticancer Drug Development. Nat. Rev. Drug Discov. 2013, 12, 847-865. [CrossRef]

72. Rottiers, V.; Näär, A.M. MicroRNAs in Metabolism and Metabolic Disorders. Nat. Rev. Mol. Cell Biol. 2012, 13, 239-251. [CrossRef] [PubMed]

73. Peng, Y.; Croce, C.M. The Role of MicroRNAs in Human Cancer. Signal. Transduct. Target. Ther. 2016, 1, 15004. [CrossRef]

74. Gholaminejad, A.; Zare, N.; Dana, N.; Shafie, D.; Mani, A.; Javanmard, S.H. A Meta-Analysis of MicroRNA Expression Profiling Studies in Heart Failure. Heart Fail. Rev. 2021, 26, 997-1021. [CrossRef]

75. Kaur, A.; Mackin, S.T.; Schlosser, K.; Wong, F.L.; Elharram, E.; Delles, C.; Stewart, D.J.; Dayan, N.; Landry, T.; Pilote, L. Systematic Review of MicroRNA Biomarkers in Acute Coronary Syndrome and Stable Coronary Artery Disease. Cardiovasc. Res. 2020, 116, 1113-1124. [CrossRef]

76. Navickas, R.; Gal, D.; Laucevicius, A.; Taparauskaite, A.; Zdantye, M.; Holvoet, P. Identifying Circulating MicroRNAs as Biomarkers of Cardiovascular Disease: A Systematic Review. Cardiovasc. Res. 2016, 111, 322-337. [CrossRef]

77. Howell, S.J.; Brown, O.I.; Beattie, W.S. Aetiology of Perioperative Myocardial Injury: A Scientific Conundrum with Profound Clinical Implications. Br. J. Anaesth. 2020, 125, 642-646. [CrossRef] [PubMed]

78. Włodarski, A.; Strycharz, J.; Wróblewski, A.; Kasznicki, J.; Drzewoski, J.; Śliwińska, A. The role of MicroRNAs in metabolic syndrome-related oxidative stress. Int. J. Mol. Sci. 2020, 21, 6902. [CrossRef] [PubMed]

79. Fu, Y.; Zhang, Y.; Wang, Z.; Wang, L.; Wei, X.; Zhang, B.; Wen, Z.; Fang, H.; Pang, Q.; Yi, F. Regulation of NADPH oxidase activity is associated with miRNA-25-mediated NOX4 expression in experimental diabetic nephropathy. Am. J. Nephrol. 2010, 32, 581-589. [CrossRef]

80. Oh, H.J.; Kato, M.; Deshpande, S.; Zhang, E.; Sadhan, D.; Lanting, L.; Wang, M.; Natarajan, R. Inhibition of the processing of miR-25 by HIPK2-Phosphorylated-MeCP2 induces NOX4 in early diabetic nephropathy. Sci. Rep. 2016, 6, 38789. [CrossRef]

81. Liu, Y.; Li, H.; Liu, J.; Han, P.; Li, X.; Bai, H.; Zhang, C.; Sun, X.; Teng, Y.; Zhang, Y.; et al. Variations in MicroRNA-25 expression influence the severity of diabetic kidney disease. J. Am. Soc. Nephrol. 2017, 28, 3627-3638. [CrossRef]

82. Wahlquist, C.; Jeong, D.; Rojas-Muñoz, A.; Kho, C.; Lee, A.; Mitsuyama, S.; van Mil, A.; Park, W.J.; Sluijter, J.P.; Doevendans, P.A.; et al. Inhibition of miR-25 improves cardiac contractility in the failing heart. Nature 2014, 508, 531-535. [CrossRef]

83. Wang, H.J.; Huang, Y.L.; Shih, Y.Y.; Wu, H.Y.; Peng, C.T.; Lo, W.Y. MicroRNA-146a Decreases High Glucose/Thrombin-Induced Endothelial Inflammation by Inhibiting NAPDH Oxidase 4 Expression. Mediators Inflamm. 2015, 2014, 379537. [CrossRef] [PubMed]

84. Shen, J.; Li, G.; Zhu, Y.; Qingsheng, X.; Zhou, H.; Xu, K.; Huang, K.; Zhan, R.; Pan, J. Foxo1-induced miR-92b down-regulation promotes blood-brain barrier damage after ischaemic stroke by targeting NOX4. J. Cell. Mol. Med. 2021, 25, 5269-5282. [CrossRef] [PubMed]

85. Zhou, T.; Li, S.; Yang, L.; Xiang, D. microRNA-363-3p reduces endothelial cell inflammatory responses in coronary heart disease via inactivation of the NOX4-dependent p38 MAPK axis. Aging 2021, 13, 11061-11082. [CrossRef]

86. Wang, Y.; Zhao, X.; Wu, X.; Dai, Y.; Chen, P.; Xie, L. MicroRNA-182 mediates sirt1-induced diabetic corneal nerve regeneration. Diabetes 2016, 65, 2020-2031. [CrossRef]

87. Li, P.; Fan, C.; Cai, Y.; Fang, S.; Zeng, Y.; Zhang, Y.; Lin, X.; Zhang, H.; Xue, Y.; Guan, M. Transplantation of brown adipose tissue up-regulates miR-99a to ameliorate liver metabolic disorders in diabetic mice by targeting NOX4. Adipocyte 2020, 9, 57-67. [CrossRef] [PubMed] 
88. Gu, C.; Draga, D.; Zhou, C.; Su, T.; Zou, C.; Gu, Q.; Lahm, T.; Zheng, Z.; Qiu, Q. MiR-590-3p inhibits pyroptosis in diabetic retinopathy by targeting NLRP1 and inactivating the NOX4 signaling pathway. Investig. Ophthalmol. Vis. Sci. 2019, 60, 4215-4223. [CrossRef]

89. Xu, Y.; Zhang, J.; Fan, L.; He, X. miR-423-5p suppresses high-glucose-induced podocyte injury by targeting Nox4. Biochem. Biophys. Res. Commun. 2018, 505, 339-345. [CrossRef]

90. Liang, Y.; Xu, J.; Wang, Y.; Tang, J.Y.; Yang, S.L.; Xiang, H.G.; Wu, S.X.; Li, X.J. Inhibition of MiRNA-125b Decreases Cerebral Ischemia/Reperfusion Injury by Targeting CK2 $\alpha / \mathrm{NADPH}$ Oxidase Signaling. Cell. Physiol. Biochem. 2018, 45, 1818-1826. [CrossRef]

91. Liu, Z.; Tuo, Y.H.; Chen, J.W.; Wang, Q.Y.; Li, S.; Li, M.C.; Dai, G.; Wang, J.S.; Zhang, Y.L.; Feng, L.; et al. NADPH oxidase inhibitor regulates microRNAs with improved outcome after mechanical reperfusion. J. Neurointerv. Surg. 2017, 9, 702-706. [CrossRef] [PubMed]

92. Jadhav, V.S.; Krause, K.H.; Singh, S.K. HIV-1 Tat C modulates NOX2 and NOX4 expressions through miR-17 in a human microglial cell line. J. Neurochem. 2014, 131, 803-815. [CrossRef]

93. Yang, J.; Brown, M.E.; Zhang, H.; Martinez, M.; Zhao, Z.; Bhutani, S.; Yin, S.; Trac, D.; Xi, J.J.; Davis, M.E. High-throughput screening identifies microRNAs that target Nox2 and improve function after acute myocardial infarction. Am. J. Physiol. Heart Circ. Physiol. 2017, 312, 1002-1012. [CrossRef] [PubMed]

94. Kyrychenko, S.; Kyrychenko, V.; Badr, M.A.; Ikeda, Y.; Sadoshima, J.; Shirokova, N. Pivotal role of MIR-448 in the development of ROS-induced cardiomyopathy. Cardiovasc. Res. 2015, 108, 324-334. [CrossRef] [PubMed]

95. Shen, W.; Lu, Y.; Hu, J.; Le, H.; Yu, W.; Xu, W.; Yu, W.; Zheng, J. Mechanism of miR-320 in Regulating Biological Characteristics of Ischemic Cerebral Neuron by Mediating Nox2/ROS Pathway. J. Mol. Neurosci. 2020, 70, 449-457. [CrossRef]

96. Li, J.; Hui, L.; Kang, Q.; Li, R. Down-regulation of microRNA-27b promotes retinal pigment epithelial cell proliferation and migration by targeting Nox2. Pathol. Res. Pract. 2018, 214, 925-933. [CrossRef]

97. Zhang, C.; Wang, J.; Ma, X.; Wang, W.; Zhao, B.; Chen, Y.; Chen, C.; Bihl, J.C. ACE2-EPC-EXs protect ageing ECs against hypoxia/reoxygenation-induced injury through the miR-18a/Nox2/ROS pathway. J. Cell. Mol. Med. 2018, 22, 1873-1882. [CrossRef]

98. Liu, H.; Wang, J.; Chen, Y.; Chen, Y.; Ma, X.; Bihl, J.C.; Yang, Y. NPC-EXs alleviate endothelial oxidative stress and dysfunction through the MIR-210 downstream Nox2 and VEGFR2 pathways. Oxid. Med. Cell. Longev. 2017, 2017, 9397631. [CrossRef] [PubMed]

99. Lew, W.Y.; Bayna, E.; Dalle Molle, E.; Contu, R.; Condorelli, G.; Tang, T. Myocardial fibrosis induced by exposure to subclinical lipopolysaccharide is associated with decreased miR-29c and enhanced NOX2 expression in mice. PLoS ONE 2014, 9, e107556. [CrossRef]

100. Li, S.Z.; Hu, Y.Y.; Zhao, J.; Zhao, Y.B.; Sun, J.D.; Yang, Y.F.; Ji, C.C.; Liu, Z.B.; Cao, W.D.; Qu, Y.; et al. MicroRNA-34a induces apoptosis in the human glioma cell line, A172, through enhanced ROS production and NOX2 expression. Biochem. Biophys. Res. Commun. 2014, 444, 6-12. [CrossRef]

101. Duan, H.; Li, Y.; Yan, L.; Yang, H.; Wu, J.; Qian, P.; Li, B.; Wang, S. MicroRNA-217 Suppresses Homocysteine-Induced Proliferation and Migration of Vascular Smooth Muscle Cells via N-Methyl-D-Aspartic Acid Receptor Inhibition. Clin. Exp. Pharmacol. Physiol. 2016, 43, 967-975. [CrossRef]

102. Zou, T.; Zhang, J.; Liu, Y.; Zhang, Y.; Sugimoto, K.; Mei, C. Antidepressant-Like Effect of Geniposide in Mice Exposed to a Chronic Mild Stress Involves the MicroRNA-298-5p-Mediated Nox1. Front. Mol. Neurosci. 2021, 13, 131. [CrossRef] [PubMed]

103. Yeligar, S.M.; Mehta, A.J.; Harris, F.L.; Brown, L.A.S.; Hart, C.M. Pioglitazone Reverses Alcohol-Induced Alveolar Macrophage Phagocytic Dysfunction. J. Immunol. 2021, 207, 483-492. [CrossRef]

104. Xiong, Y.; Chen, L.; Yu, T.; Yan, C.; Zhou, W.; Cao, F.; You, X.; Zhang, Y.; Sun, Y.; Liu, J.; et al. Inhibition of Circulating Exosomal MicroRNA-15a-3p Accelerates Diabetic Wound Repair. Aging 2020, 12, 8968-8986. [CrossRef] [PubMed]

105. Ge, Q.-M.; Huang, C.-M.; Zhu, X.-Y.; Bian, F.; Pan, S.-M. Differentially Expressed MiRNAs in Sepsis-Induced Acute Kidney Injury Target Oxidative Stress and Mitochondrial Dysfunction Pathways. PLoS ONE 2017, 12, e0173292. [CrossRef]

106. Wu, J.; Lu, K.; Zhu, M.; Xie, X.; Ding, Y.; Shao, X.; Chen, Y.; Liu, J.; Xu, M.; Xu, Y.; et al. MiR-485 Suppresses Inflammation and Proliferation of Mesangial Cells in an in Vitro Model of Diabetic Nephropathy by Targeting NOX5. Biochem. Biophys. Res. Commun. 2020, 521, 984-990. [CrossRef]

107. Czech, M. Insulin action and resistance in obesity and type 2 diabetes. Nat. Med. 2018, 23, 804-814. [CrossRef]

108. Steinberg, H.O.; Chaker, H.; Leaming, R.; Johnson, A.; Brechtel, G.; Baron, A. Obesity/insulin resistance is associated with endothelial dysfunction. Implications for the syndrome of insulin resistance. J. Clin. Investig. 1996, 97, 2601-2610. [CrossRef]

109. Zeng, G.; Nystrom, F.H.; Ravichandran, L.V.; Cong, L.N.; Kirby, M.; Mostowski, H.; Quon, M.J. Roles for insulin receptor, PI3-kinase, and Akt in insulin-signaling pathways related to production of nitric oxide in human vascular endothelial cells. Circulation 2000, 101, 1539-1545. [CrossRef]

110. Zeng, G.; Quon, M.J. Insulin-stimulated production of nitric oxide is inhibited by Wortmannin: Direct measurement in vascular endothelial cells. J. Clin. Investig. 1996, 98, 894-898. [CrossRef] [PubMed]

111. Dimmeler, S.; Fleming, I.; Fisslthaler, B.; Hermann, C.; Busse, R.; Zeiher, A. Activation of nitric oxide synthase in endothelial cells by Akt-dependent phosphorylation. Nature 1999, 399, 601-605. [CrossRef] 
112. Volpe, C.M.O.; Villar-Delfino, P.H.; Dos Anjos, P.M.F.; Nogueira-Machado, J.A. Cellular death, reactive oxygen species (ROS) and diabetic complications. Cell Death Dis. 2018, 25, 119. [CrossRef]

113. Kohnert, K.-D.; Freyse, E.-J.; Salzsieder, E. Glycaemic variability and pancreatic $\beta$-cell dysfunction. Curr. Diabetes Rev. 2012, 8, 345-354. [CrossRef]

114. Riemer, J.; Bulleid, N.; Herrmann, J.M. Disulfide Formation in the ER and Mitochondria: Two Solutions to a Common Process. Science 2009, 324, 1284-1287. [CrossRef]

115. Bhandary, B.; Marahatta, A.; Kim, H.R.; Chae, H.J. An involvement of oxidative stress in endoplasmic reticulum stress and its associated diseases. Int. J. Mol. Sci. 2013, 14, 434-456. [CrossRef]

116. Yamagishi, S.; Matsui, T. Role of Hyperglycemia-Induced Advanced Glycation End Product (AGE) Accumulation in Atherosclerosis. Ann. Vasc. Dis. 2018, 11, 253-258. [CrossRef] [PubMed]

117. Wautier, M.P.; Chappey, O.; Corda, S.; Stern, D.M.; Schmidt, A.M.; Wautier, J.L. Activation of NADPH oxidase by AGE links oxidant stress to altered gene expression via RAGE. Am. J. Physiol. Endocrinol. Metab. 2001, 280, 685-694. [CrossRef]

118. Bucciarelli, L.G.; Wendt, T.; Qu, W.; Lu, Y.; Lalla, E.; Rong, L.L.; Goova, M.T.; Moser, B.; Kislinger, T.; Lee, D.C.; et al. RAGE blockade stabilizes established atherosclerosis in diabetic apolipoprotein E-null mice. Circulation 2002, 106, 2827-2835. [CrossRef] [PubMed]

119. Schalkwijk, C.G.; Stehouwer, C.D.A. Methylglyoxal, a Highly Reactive Dicarbonyl Compound, in Diabetes, Its Vascular Complications, and Other Age-Related Diseases. Physiol. Rev. 2020, 100, 407-461. [CrossRef] [PubMed]

120. Ho, C.; Lee, P.-H.; Huang, W.-J.; Hsu, Y.-C.; Lin, C.-L.; Wang, J.-Y. Methylglyoxal-Induced Fibronectin Gene Expression through Ras-Mediated NADPH Oxidase Activation in Renal Mesangial Cells. Nephrology 2007, 12, 348-356. [CrossRef]

121. Tournier, C.; Whitmarsh, A.; Cavanagh, J.; Barrett, T.; Davis, R. Mitogen-Activated Protein Kinase Kinase 7 Is an Activator of the c-Jun NH2-Terminal Kinase. Proc. Natl. Acad. Sci. USA 1997, 94, 7337-7342. [CrossRef] [PubMed]

122. Kusari, A.B.; Byon, J.; Bandyopadhyay, D.; Kenner, K.A.; Kusari, J. Insulin-Induced Mitogen-Activated Protein (MAP) Kinase Phosphatase-1 (MKP-1) Attenuates Insulin-Stimulated MAP Kinase Activity: A Mechanism for the Feedback Inhibition of Insulin Signaling. Mol. Endocrinol. 1997, 11, 1532-1543. [CrossRef]

123. Liu, Y.; Shepherd, E.G.; Nelin, L.D. MAPK Phosphatases-Regulating the Immune Response. Nat. Rev. Immunol. 2007, 7, $202-212$. [CrossRef]

124. Kamata, H.; Honda, S.; Maeda, S.; Chang, L.; Hirata, H.; Karin, M. Reactive Oxygen Species Promote TNFalpha-Induced Death and Sustained JNK Activation by Inhibiting MAP Kinase Phosphatases. Cell 2005, 11, 649-661. [CrossRef]

125. De Luca, C.; Olefsky, J.M. Inflammation and Insulin Resistance. FEBS. Lett. 2008, 582, 97-105. [CrossRef]

126. Wu, H.; Ballantyne, C.M. Metabolic Inflammation and Insulin Resistance in Obesity. Circ. Res. 2020, 126, 1549-1564. [CrossRef]

127. Gray, S.P.; di Marco, E.; Okabe, J.; Szyndralewiez, C.; Heitz, F.; Montezano, A.C.; de Haan, J.B.; Koulis, C.; El-Osta, A.; Andrews, K.L.; et al. NADPH Oxidase 1 Plays a Key Role in Diabetes Mellitus-Accelerated Atherosclerosis. Circulation 2013, 127, 1888-1902. [CrossRef] [PubMed]

128. Wilkinson-Berka, J.L.; Deliyanti, D.; Rana, I.; Miller, A.G.; Agrotis, A.; Armani, R.; Szyndralewiez, C.; Wingler, K.; Touyz, R.M.; Cooper, M.E.; et al. NADPH Oxidase, NOX1, Mediates Vascular Injury in Ischemic Retinopathy. Antioxid. Redox Signal. 2014, 20, 2726-2740. [CrossRef]

129. Deliyanti, D.; Alrashdi, S.F.; Touyz, R.M.; Kennedy, C.R.; Jha, J.C.; Cooper, M.E.; Jandeleit-Dahm, K.A.; Wilkinson-Berka, J.L. Nox (NADPH Oxidase) 1, Nox4, and Nox5 Promote Vascular Permeability and Neovascularization in Retinopathy. Hypertension 2020, 75, 1091-1101. [CrossRef]

130. Muñoz, M.; López-Oliva, M.E.; Rodríguez, C.; Martínez, M.P.; Sáenz-Medina, J.; Sánchez, A.; Climent, B.; Benedito, S.; GarcíaSacristán, A.; Rivera, L.; et al. Differential Contribution of Nox1, Nox2 and Nox4 to Kidney Vascular Oxidative Stress and Endothelial Dysfunction in Obesity. Redox Biol. 2020, 28, 101330. [CrossRef] [PubMed]

131. You, Y.H.; Okada, S.; Ly, S.; Jandeleit-Dahm, K.; Barit, D.; Namikoshi, T.; Sharma, K. Role of Nox2 in diabetic kidney disease. Am. J. Physiol. Ren. Physiol. 2013, 304, 840-848. [CrossRef] [PubMed]

132. Forte, M.; Nocella, C.; De Falco, E.; Palmerio, S.; Schirone, L.; Valenti, V.; Frati, G.; Carnevale, R.; Sciarretta, S. The Pathophysiological Role of NOX2 in Hypertension and Organ Damage. High Blood Press. Cardiovasc. Prev. 2016, 23, 355-364. [CrossRef]

133. Krijnen, P.A.J.; Meischl, C.; Hack, C.E.; Meijer, C.J.L.M.; Visser, C.A.; Roos, D.; Niessen, H.W.M. Increased Nox2 expression in human cardiomyocytes after acute myocardial infarction. J. Clin. Pathol. 2003, 56, 194-199. [CrossRef]

134. Barua, S.; Kim, J.Y.; Yenari, M.A.; Lee, J.E. The role of NOX inhibitors in neurodegenerative diseases. IBRO Rep. 2019,7 , 59-69. [CrossRef]

135. Vicent, D.; Ilany, J.; Kondo, T.; Naruse, K.; Fisher, S.J.; Kisanuki, Y.Y.; Bursell, S.; Yanagisawa, M.; King, G.L.; Kahn, C.R. The role of endothelial insulin signaling in the regulation of vascular tone and insulin resistance. J. Clin. Investig. 2003, 111, 1373-1380. [CrossRef] [PubMed]

136. De Figueiredo, A.S.P.; Salmon, A.B.; Bruno, F.; Jimenez, F.; Martinez, H.G.; Halade, G.V.; Ahuja, S.S.; Clark, R.A.; DeFronzo, R.A.; Abboud, H.E.; et al. Nox2 mediates skeletal muscle insulin resistance induced by a high fat diet. J. Biol. Chem. 2015, 290, 13427-13439. [CrossRef] [PubMed]

137. Rojas, M.; Zhang, W.; Xu, Z.; Lemtalsi, T.; Chandler, P.; Toque, H.A.; Caldwell, R.W.; Caldwell, R.B. Requirement of NOX2 expression in both retina and bone marrow for diabetes-induced retinal vascular injury. PLoS ONE 2013, 8, e84357. [CrossRef] [PubMed] 
138. Al-Shabrawey, M.; Bartoli, M.; El-Remessy, A.B.; Ma, G.; Matragoon, S.; Lemtalsi, T.; Caldwell, R.W.; Caldwell, R.B. Role of NADPH oxidase and Stat3 in statin-mediated protection against diabetic retinopathy. Investig. Ophthalmol. Vis. Sci. 2008, 49, 3231-3238. [CrossRef]

139. Rojas, M.; Lemtalsi, T.; Toque, H.; Xu, Z.; Fulton, D.; Caldwell, R.; Caldwell, R. NOX2-Induced Activation of Arginase and Diabetes-Induced Retinal Endothelial Cell Senescence. Antioxidants 2017, 6, 43. [CrossRef]

140. Lener, B.; Kozieł, R.; Pircher, H.; Hütter, E.; Greussing, R.; Herndler-Brandstetter, D.; Hermann, M.; Unterluggauer, H.; JansenDürr, P. The NADPH oxidase Nox4 restricts the replicative lifespan of human endothelial cells. Biochem. J. 2009, 423, 363-374. [CrossRef]

141. Seleem, M.; Shabayek, M.; Ewida, H.A. MicroRNAs 342 and 450 together with NOX-4 activity and their association with coronary artery disease in diabetes. Diabetes Metab. Res. Rev. 2019, 35, e3130. [CrossRef]

142. Viswambharan, H.; Yuldasheva, N.Y.; Imrie, H.; Bridge, K.; Haywood, N.J.; Skromna, A.; Hemmings, K.E.; Clark, E.R.; Gatenby, V.K.; Cordell, P.; et al. Novel Paracrine Action of Endothelium Enhances Glucose Uptake in Muscle and Fat. Circ. Res. 2021. [CrossRef] [PubMed]

143. Ray, R.; Murdoch, C.E.; Wang, M.; Santos, C.X.; Zhang, M.; Alom-Ruiz, S.; Anilkumar, N.; Ouattara, A.; Cave, A.C.; Walker, S.J.; et al. Endothelial Nox4 NADPH oxidase enhances vasodilatation and reduces blood pressure in vivo. Arterioscler. Thromb. Vasc. Biol. 2011, 31, 1368-1376. [CrossRef] [PubMed]

144. Craige, S.M.; Chen, K.; Pei, Y.; Li, C.; Huang, X.; Chen, C.; Shibata, R.; Sato, K.; Walsh, K.; Keaney, J.F. NADPH Oxidase 4 promotes endothelial angiogenesis through endothelial nitric oxide synthase activation. Circulation 2011, 124, 731-740. [CrossRef] [PubMed]

145. Schroder, K.; Zhang, M.; Benkhoff, S.; Mieth, A.; Pliquett, R.; Kosowski, J.; Kruse, C.; Luedike, P.; Michaelis, U.; Weissmann, N.; et al. Nox4 is a protective reactive oxygen species generating vascular NADPH oxidase. Circ. Res. 2012, 110, 1217-1225. [CrossRef] [PubMed]

146. Datla, S.R.; Peshavariya, H.; Dusting, G.J.; Mahadev, K.; Goldstein, B.J.; Jiang, F. Important role of Nox4 type NADPH oxidase in angiogenic responses in human microvascular endothelial cells in vitro. Arterioscler. Thromb. Vasc. Biol. 2007, 27, $2319-2324$. [CrossRef]

147. Hakami, N.Y.; Ranjan, A.K.; Hardikar, A.A.; Dusting, G.J.; Peshavariya, H.M. Role of NADPH Oxidase-4 in human endothelial progenitor cells. Front. Physiol. 2017, 8, 150. [CrossRef] [PubMed]

148. O'Neill, K.M.; Campbell, D.C.; Edgar, K.S.; Gill, E.K.; Moez, A.; McLoughlin, K.J.; O’Neill, C.L.; Dellett, M.; Hargey, C.J.; Abudalo, R.A.; et al. NOX4 is a major regulator of cord blood-derived endothelial colony-forming cells which promotes post-ischaemic revascularization. Cardiovasc. Res. 2020, 116, 393-405. [CrossRef] [PubMed]

149. Schürmann, C.; Rezende, F.; Kruse, C.; Yasar, Y.; Löwe, O.; Fork, C.; Van De Sluis, B.; Bremer, R.; Weissmann, N.; Shah, A.M.; et al. The NADPH oxidase Nox4 has anti-atherosclerotic functions. Eur. Heart. J. 2015, 36, 3447-3456. [CrossRef]

150. Langbein, H.; Brunssen, C.; Hofmann, A.; Cimalla, P.; Brux, M.; Bornstein, S.R.; Deussen, A.; Koch, E.; Morawietz, H. NADPH oxidase 4 protects against development of endothelial dysfunction and atherosclerosis in LDL receptor deficient mice. Eur. Heart. J. 2016, 37, 1753-1761. [CrossRef]

151. Specht, K.S.; Kant, S.; Addington, A.K.; McMillan, R.P.; Hulver, M.W.; Learnard, H.; Campbell, M.; Donnelly, S.R.; Caliz, A.D.; Pei, Y.; et al. Nox4 mediates skeletal muscle metabolic responses to exercise. Mol. Metab. 2021, 45, 101160. [CrossRef]

152. Brendel, H.; Shahid, A.; Hofman, A.; Mittag, J.; Bornstein, S.; Morawietz, H.; Brunssen, C. NADPH oxidase 4 mediates the protective effects of physical activity against obesity-induced vascular dysfunction. Cardiovasc. Res. 2020, 116, 1767-1778. [CrossRef]

153. Pi, X.; Xie, L.; Portbury, A.L.; Kumar, S.; Lockyer, P.; Li, X.; Patterson, C. NADPH Oxidase-Generated Reactive Oxygen Species Are Required for Stromal Cell-Derived Factor-1 $\alpha$-Stimulated Angiogenesis. Arterioscler. Thromb. Vasc. Biol. 2014, 34, $2023-2032$. [CrossRef] [PubMed]

154. Touyz, R.M.; Anagnostopoulou, A.; Rios, F.; Montezano, A.C.; Camargo, L.L. NOX5: Molecular Biology and Pathophysiology. Exp. Physiol. 2019, 104, 605-616. [CrossRef] [PubMed]

155. Jha, J.C.; Watson, A.M.D.; Mathew, G.; de Vos, L.C.; Jandeleit-Dahm, K. The Emerging Role of NADPH Oxidase NOX5 in Vascular Disease. Clin. Sci. 2017, 131, 981-990. [CrossRef] [PubMed]

156. Elbatreek, M.H.; Sadegh, S.; Anastasi, E.; Guney, E.; Nogales, C.; Kacprowski, T.; Hassan, A.A.; Teubner, A.; Huang, P.-H.; Hsu, C.-Y.; et al. NOX5-Induced Uncoupling of Endothelial NO Synthase Is a Causal Mechanism and Theragnostic Target of an Age-Related Hypertension Endotype. PLoS Biol. 2020, 18, e3000885. [CrossRef]

157. Marqués, J.; Cortés, A.; Pejenaute, Á.; Ansorena, E.; Abizanda, G.; Prósper, F.; Martínez-Irujo, J.J.; de Miguel, C.; Zalba, G. Induction of Cyclooxygenase-2 by Overexpression of the Human NADPH Oxidase 5 (NOX5) Gene in Aortic Endothelial Cells. Cells 2020, 9, 637. [CrossRef]

158. Maraldi, T. Natural Compounds as Modulators of NADPH Oxidases. Oxid. Med. Cell. Longev. 2013, 2013, 271602. [CrossRef]

159. Bjelakovic, G.; Nikolova, D.; Gluud, L.L.; Simonetti, R.G.; Gluud, C. Antioxidant Supplements for Prevention of Mortality in Healthy Participants and Patients with Various Diseases. Cochrane Database Syst. Rev. 2012, CD007176. [CrossRef]

160. Altenhöfer, S.; Radermacher, K.A.; Kleikers, P.W.M.; Wingler, K.; Schmidt, H.H.H.W. Evolution of NADPH Oxidase Inhibitors: Selectivity and Mechanisms for Target Engagement. Antioxid. Redox Signal. 2015, 23, 406-427. [CrossRef] 
161. Jacobson, G.M.; Dourron, H.M.; Liu, J.; Carretero, O.A.; Reddy, D.J.; Andrzejewski, T.; Pagano, P.J. Novel NAD(P)H Oxidase Inhibitor Suppresses Angioplasty-Induced Superoxide and Neointimal Hyperplasia of Rat Carotid Artery. Circ. Res. 2003, 92, 637-643. [CrossRef] [PubMed]

162. Sedeek, M.; Callera, G.; Montezano, A.; Gutsol, A.; Heitz, F.; Szyndralewiez, C.; Page, P.; Kennedy, C.R.J.; Burns, K.D.; Touyz, R.M.; et al. Critical Role of Nox4-Based NADPH Oxidase in Glucose-Induced Oxidative Stress in the Kidney: Implications in Type 2 Diabetic Nephropathy. Am. J. Physiol. Renal. Physiol. 2010, 299, 1348-1358. [CrossRef] [PubMed]

163. De Livera, A.M.; Reutens, A.; Reutens, A.; Cooper, M.; Thomas, M.; Jandeleit-Dahm, K.; Shaw, J.E.; Shaw, J.E.; Salim, A.; Salim, A. Evaluating the Efficacy and Safety of GKT137831 in Adults with Type 1 Diabetes and Persistently Elevated Urinary Albumin Excretion: A Statistical Analysis Plan. Trials 2020, 21, 459. [CrossRef] [PubMed]

164. Grieco, G.E.; Brusco, N.; Licata, G.; Nigi, L.; Formichi, C.; Dotta, F.; Sebastiani, G. Targeting MicroRNAs as a Therapeutic Strategy to Reduce Oxidative Stress in Diabetes. Int. J. Mol. Sci. 2019, 20, 6358. [CrossRef]

165. Hanna, J.; Hossain, G.S.; Kocerha, J. The Potential for MicroRNA Therapeutics and Clinical Research. Front. Genet. 2019, 10, 478. [CrossRef] 